\title{
Soil metals, chloroplasts, and secure crop production: a review
}

\author{
Katalin Solymosi $\cdot$ Martine Bertrand
}

Accepted: 6 December 2010/Published online: 29 April 2011

(C) INRA and Springer Science+Business Media B.V. 2011

\begin{abstract}
An increasing number of soils of poor quality with unbalanced metal concentrations are used worldwide for crop cultivation. Even though plants are able to develop strategies to cope with metal stress, either metal deficiency or excess, this unbalance affects the whole plant. Chloroplasts are key organelles for organic matter synthesis and biomass production. Under metal stress, chloroplasts suffer severe alterations of their ultrastructure, associated with profound molecular and metabolic damages. These alterations are accompanied by unbalanced metal distribution in plants, in particular in edible crop organs. Toxic metals get either accumulated or there is a deficiency of nutrients, resulting in a weak nutritional value. Nonetheless, there is more and more knowledge on the functioning and regulation of metal transporters in plants. Such knowledge will allow growing crops with well-balanced metal concentrations in edible parts even on metal unbalanced soils. This review shows that almost all vital functions of chloroplasts, such as photosynthesis, $\mathrm{CO}_{2}$ fixation, nitrogen and sulfur assimilation, and protein and nucleic acid metabolism, require metals. Therefore, the uptake of essential metals is necessary for the proper functioning of chloroplasts and, in turn, for crop productivity. We
\end{abstract}

\section{K. Solymosi}

Department of Plant Anatomy, Institute of Biology,

Eötvös University,

1117 Pázmány P. s. 1/C,

Budapest, Hungary

M. Bertrand $(\square)$

National Institute for Marine Sciences and Techniques, CNAM, BP 324, 50103 Cherbourg-Octeville Cedex, France e-mail: martine.bertrand@cnam.fr describe nutrient uptake mechanisms of plants and processes that influence essential and non-essential metal concentrations in different plant organs. We present an overview of metal transporters in chloroplasts. Several questions still need to be elucidated about the uptake and the trafficking of essential and non-essential metals into and within chloroplasts. Similarly to transporters present in other cellular compartments, the carriers are often not metal-specific. Therefore, essential and non-essential metals may compete for carriers. As a result, unbalanced soil metal concentrations can be reflected in the plants and in the chloroplasts. Metal deficiency or excess causes reduced growth and decreased productivity of crops. It can lead to human malnutrition. Several complex physiological processes can be responsible for the reduced biomass observed in plants with unbalanced metal concentration. In this review, we have focused on the structural and functional alterations of chloroplasts under metal deficiency or excess. Interestingly, besides specific differences, our data indicate several similarities in the response of chloroplasts to metal deficiency or excess. Indeed, oxidative stress and several ultrastructural alterations, e.g., increase in the number and size of plastoglobuli, disorganized grana and disturbed thylakoids, and swelling of the intrathylakoidal space, are observed in both cases. This indicates that changes in chloroplast ion homeostasis rather than the specific effect of a metal are responsible for decreased plant productivity. Therefore, sustainable agriculture has to take into consideration solutions that enable undisturbed metal and ion homeostasis in chloroplasts of crop plants grown even in soils with unbalanced metal concentrations.

Keywords Biofortification $\cdot$ Chloroplast $\cdot$ Metal deficiency $\cdot$ Metal excess $\cdot$ Metal excluder $\cdot$ Metals $\cdot$ Metal transporter $\cdot$ Phytoextraction $\cdot$ Photosynthesis $\cdot$ Soil 


\section{Contents}

1. Introduction. . . . . . . . . . . . . . . 2

2. Metal requirement of plants and their roles

with emphasis on chloroplasts. . . . . . . . . . . 2

3. Metal transport from soil to chloroplasts. . . . . . . 4 4

3.1. Metals in soil. . . . . . . . . . . . . . 7

3.2. Metal transport: from the roots to other plant organs.................... 4

3.3. Metals can also enter the plant through the

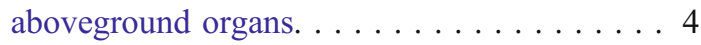

3.4. Chloroplasts as metal targets. ........... 5

3.5. Cross talk between different metals. . . . . . . . 5

4. Impact of metal deficiency. . . . . . . . . . 5

4.1. Molecular and metabolic alterations in chloroplasts. .................... 6

4.2. Ultrastructural alterations of chloroplasts. . . . 6

4.3. Alterations on the level of the entire plant. . . . . 7

5. Impact of metal excess. . . . . . . . . . . . 7

5.1. Molecular and metabolic alterations in chloroplasts. . . . . . . . . . . . . . 7 5.1.1. Metal-induced oxidative burst. . . . . . . 7 5.1.2. Synthesis of molecules trapping metals. . 8 5.1.3. Molecules impacted by metals. . . . . . .9 5.2. Ultrastructural alterations of chloroplasts. . . . 12 5.3. Alterations on the level of the entire plant. . . . 13 6. Conclusions and perspectives. . . . . . . . . . 14 7. Acknowledgments. . . . . . . . . . . . . . 15 8. References . . . . . . . . . . . . . . . . 15

\section{Introduction}

The growth of the world's population exerts a very strong pressure on food production. In order to satisfy the demand, more food must be produced, which necessitates the use of soils of poor quality, i.e., soils having unbalanced metal content (see, e.g., Adams et al. 2000; Wilson and Pyatt 2007; reviewed by Hagemeyer 2006; Wei and Zhou 2008). In addition, the gradual decline in the availability of freshwater for irrigation leads to the use of sewage sludge (e.g., El-Naim et al. 2004; Rattan et al. 2005; Antonious and Snyder 2007; Singh and Agrawal 2007; Jamali et al. 2009) or other wastewaters (e.g., Mapanda et al. 2005; Sahn et al. 2007; Arora et al. 2008; Nair et al. 2008).

Numerous papers have reported the impact of metal unbalance on plant development and productivity and also on the strategies developed by plants to cope with these conditions. However, even if plants have the capacity to compensate the unbalance and to keep on growing to some extent in a polluted environment, this does not mean that their nutritive quality is acceptable because their essential element content can be insufficient (see, e.g., reviews by Prasad 2004; Palmgren et al. 2008) or they may contain toxic metals (see, e.g., Muchuweti et al. 2006; reviewed by Dudka and Miller 1999).

Generally absorbed by roots, most of the metals are transported toward the leaves through the stem. They are distributed according to the demand of the different cell compartments (reviewed by Poirier et al. 2008). Among these compartments, the chloroplasts appear as key organelles because they are the producers of organic matter via photosynthesis. Plastids also harbor other vital biosynthetic functions, such as nitrogen (ammonia) and sulfur assimilation or the biosynthesis of fatty acids, (aromatic) amino acids, lipids, pigments (chlorophylls and carotenoids), purines, pyrimidines, and secondary metabolites (reviewed by Seddas et al. 2009). In consequence, these functions require an active solute exchange across the chloroplast envelope. Many reactions involved in these biosynthetic processes require metals, and therefore, metal import is organized through the plastid envelopes (Fig. 1, e.g., reviewed by Weber et al. 2005; Poirier et al. 2008; Spetea and Schoefs 2011). In the frame of the development of agriculture, and in particular of sustainable agriculture, the full understanding of metal transport and metabolism in plants becomes a prerequisite for improving plant productivity on soils with unbalanced metal contents. In this respect, the chloroplast should stand in the focus of the research because all food chains depend on the functioning of chloroplast metabolism. In this work, after having recalled the metal requirements of plants, the metal translocation to chloroplasts is briefly described. Then, the impacts of metal deficiency or excess are discussed in details. The last part of this work briefly reviews perspectives about how to secure crop production with balanced metals in edible parts of plants. All along this work, metals are designated using their symbols, without any charge, in order to avoid overloading the text by too many details.

\section{Metal requirement of plants and their roles with emphasis on chloroplasts}

Metals (italicized) and metalloids (asterisk) belong to essential ( $\left.\mathrm{K}, \mathrm{Ca}, \mathrm{Mg}, \mathrm{Fe}, \mathrm{B}^{*}, \mathrm{Mn}, \mathrm{Cu}, \mathrm{Zn}, \mathrm{Mo}, \mathrm{Ni}\right)$ and non-essential elements $\left(\mathrm{Co}, \mathrm{Na}, \mathrm{Se}^{*}\right)$, the latter being beneficial for some plants only (Co: Oven et al. 2002; Na: reviewed by Subbarao et al. 2001; Se: reviewed by Sors et al. 2005). Besides the elements $\mathrm{C}, \mathrm{H}, \mathrm{O}$, and $\mathrm{N}$, those that are required in large quantities are called macronutrients (P, S, $\mathrm{K}, \mathrm{Ca}, \mathrm{Mg}$ ), whereas those that are necessary in smaller amounts are named micronutrients $\left(F e, \mathrm{~B}^{*}, \mathrm{Mn}\right.$, $\mathrm{Cu}, \mathrm{Zn}, \mathrm{Mo}, \mathrm{Cl}, \mathrm{Ni}$; reviewed by Marschner 1995). 


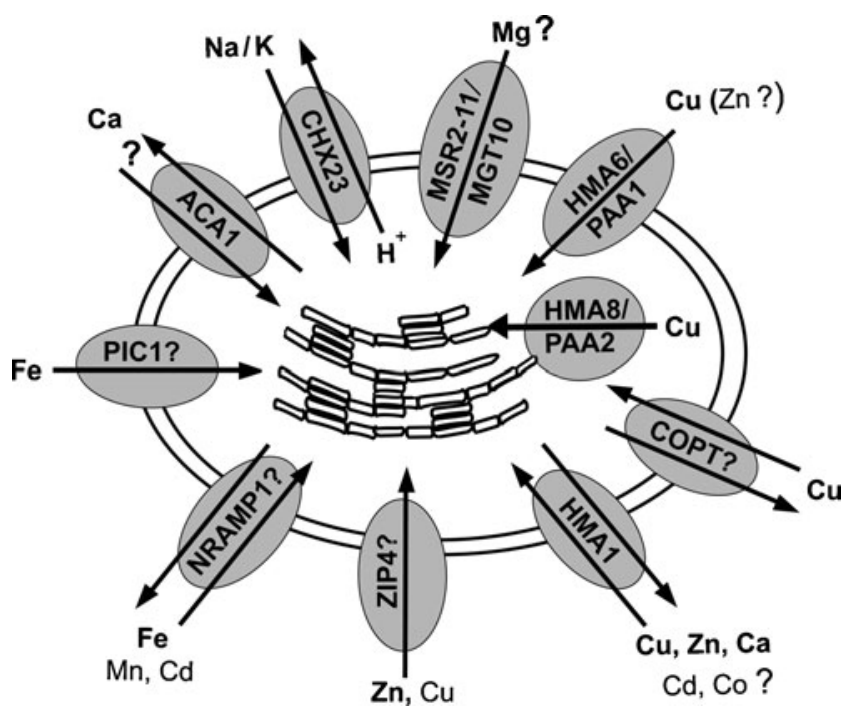

Fig. 1 Scheme presenting the most important metal transporters located to the chloroplasts. The primary transported metals are indicated in bold. The question marks stand for uncertainties, i.e., the exact localization of the protein (when the chloroplast localization of the protein is only computer-predicted, a question mark is on the protein itself); the metals transported (the question mark stands after the symbol of the metal(s) in question); or in the direction of the transport (question mark between the arrows). ACA1/PEA1: CaATPase 1 (Huang et al. 1993; White and Broadley 2003; Johnson et al. 2006); $\mathrm{CHX} 23$ : $\mathrm{Na}^{+}\left(\mathrm{K}^{+}\right) / \mathrm{H}^{+}$antiporter 23 (Song et al. 2004a); MSR2-11/MGT10: magnesium transporter (Drummond et al. 2006; Mueller-Roeber and Arvidsson 2009); HMA6/PAA1 heavy metal transporter 6 (Shikanai et al. 2003; Abdel-Ghany et al. 2005; Puig et al. 2007a; Yruela 2009); HMA8/PAA2 heavy metal transporter 8 (Shikanai et al. 2003; Abdel-Ghany et al. 2005; Puig et al. 2007a; Burkhead et al. 2009; Yruela 2009); COPT: conserved copper transporter (Sancenon et al. 2003; Burkhead et al. 2009; Yruela 2009); HMA1: heavy metal transporter 1 (Seigneurin-Berny et al. 2006; Puig et al. 2007a; Burkhead et al. 2009; Kim et al. 2009; Yruela 2009); ZIP4: ZRT, IRT-like protein 4 (Grotz et al. 1998; Hall and Williams 2003; Grotz and Guerinot 2006); NRAMP1: natural resistance-associated macrophage protein 1 (Curie et al. 2000; Thomine et al. 2000; Grotz and Guerinot 2006; Puig et al. 2007a); PIC1: permease 1 (Duy et al. 2007; Puig and Penarrubia 2009)

In the chloroplasts, similarly to other cell compartments, the metals function as structural constituents of various molecules, essentially of proteins, or are used to modulate metabolic reactions or cellular processes. Table 1 indicates the metals required by plastids and some of their important functions specific to chloroplasts. In addition to these roles, the chloroplast can serve as a storage compartment for $\mathrm{Ca}$ (Seigneurin-Berny 2000). Alternatively, chloroplasts can be involved in the cellular detoxification (rather sequestration) of excess metals such as $\mathrm{Fe}, \mathrm{Cu}$, or $\mathrm{Na}$ (for details, see Section 5.1.2).

Taken together, these data clearly indicate that practically all vital functions of chloroplasts require metals. This way, the uptake of essential metals is necessary for the proper functioning of this organelle and as a consequence for crop productivity. On the other hand, plastids also play a role in essential metal $(\mathrm{Ca}, \mathrm{Cu}, \mathrm{Fe})$ homeostasis.

\section{Metal transport from soil to chloroplasts}

Data about the total metal content of a soil give interesting information (e.g., the abundance of essential or nonessential elements), but scarcely help in predicting the metal contents and proportions found within a plant cultivated on it (Antonious and Snyder 2007; Wilson and Pyatt 2007). The main reasons for this difficulty are (1) the non-phytoavailability of some metal forms, (2) the active transport of solutes through plants, (3) the atmospheric deposition of metals on aboveground organs, (4) the competition between different metals for the uptake and transport within the plants, and (5) the possible presence of unbalanced metal concentrations already in the seeds before germination.

\subsection{Metals in soil}

Metal phytoavailability results from complex interactions between the physicochemical properties of the soil (including, e.g., $\mathrm{pH}$, presence of clay particles, complexation, organic matter, and moisture; e.g., Pinto et al. 2004; Basar 2009; reviewed by Fodor 2006) and those of the metal (chemical forms, stability, mobility, and solubility; Whiting et al. 2003; reviewed by Fodor 2006). For instance, metals are in general more soluble at low $\mathrm{pH}$, and consequently, their phytoavailability increases. Therefore, soil acidification constitutes a real problem in case of pollution (see, for example, Poschenrieder et al. 2008 for aluminum). Note that acid soil represented in 2004 approximately $50 \%$ of the world's arable soils (Kochian et al. 2004).

Although acidification may increase the essential metal availability for plants, it leads to unbalanced metal concentrations in soils and can this way lead to the accumulation of toxic concentrations of either essential or non-essential elements in plants.

\subsection{Metal transport: from the roots to other plant organs}

Plants and soil microbes possess different mechanisms that help in the acquisition of essential metals from the soil, including the lowering of the soil $\mathrm{pH}$ or excreting out different metal chelating agents (phytosiderophores or siderophores in plants and microbes, respectively; reviewed by Grusak et al. 1999; Schmidt 2003; Fodor 2006; Haydon and Cobbett 2007; Puig et al. 2007a; Kidd et al. 2009). Besides essential metal uptake, phytosiderophores may also be involved in toxic metal (e.g., $\mathrm{Al}, \mathrm{Cd}$, and $\mathrm{Pb}$ ) uptake (Hill et al. 2002; reviewed by Kochian 1995; Fodor 2006). 
Table 1 Metabolic pathways of chloroplasts and their metal requirements (non-exhaustive list of enzymes or processes)

\begin{tabular}{|c|c|}
\hline \multicolumn{2}{|c|}{ Chorophyll synthesis and breakdown } \\
\hline $\begin{array}{l}\mathrm{Co} \\
\mathrm{Fe} \\
\mathrm{Mn}\end{array}$ & $\begin{array}{l}\text { Delta-aminolevulinic acid dehydratase (Shalygo et al., 1999) } \\
\text { Delta-aminolevulinic acid synthesis (Shalygo et al., 1999) } \\
\text { Porphobilinogenase (Shalygo et al., 1999) }\end{array}$ \\
\hline $\mathrm{Ni}$ & \\
\hline $\mathrm{Fe}$ & $\begin{array}{l}\text { Chlorophyllide } a \text { oxygenase (Duy et al., 2007) } \\
\text { Conversion of Mg-protoporphyrin monomethyl ester into protochlorophyllide } \\
\text { (Myśliwa-Kurdziel and Strzałka, 2002) } \\
\text { Pheophorbide } a \text { oxygenase (Duy et al., 2007) }\end{array}$ \\
\hline $\mathrm{Mg}$ & $\begin{array}{l}\text { Delta-aminolevulinic acid dehydratase (Beale, 1999) } \\
\text { Mg-chelatase (Beale, 1999) }\end{array}$ \\
\hline \multicolumn{2}{|c|}{ Haem biosynthesis } \\
\hline $\mathrm{Fe}$ & Ferrochelatase (Cornah et al., 2002) \\
\hline \multicolumn{2}{|c|}{ Photosynthetic light reactions } \\
\hline $\mathrm{Ca}$ & Assembly of photosystem II (Raven et al., 1999) \\
\hline $\mathrm{Cu}$ & Plastocyanin (Abdel-Ghany, 2009) \\
\hline $\mathrm{Fe}$ & $\begin{array}{l}\text { Cytochrome b6-f (Raven et al., 1999) } \\
\text { Cytochrome c6 (Raven et al., 1999) } \\
\text { Ferredoxin (Tognetti et al., 2007) } \\
\text { NAD(P)H-plastoquinone oxidoreductase (Raven et al., 1999) }\end{array}$ \\
\hline $\mathrm{Mg}$ & ATP synthase (Shaul, 2002, Kucera et al., 2008) \\
\hline $\mathrm{Mn}$ & Water oxidase (Grace, 1990) \\
\hline $\mathrm{Zn}$ & ATP-dependent Zn-metalloprotease FtsH (Bailey et al., 2001) \\
\hline \multicolumn{2}{|c|}{ Carbon assimilation. } \\
\hline $\mathrm{Ca}$ & $\begin{array}{l}\text { Zn-protease degrading ribulose-1,5-bisphosphate carboxylase oxygenase (Bushnell et } \\
\text { al., 1993) }\end{array}$ \\
\hline
\end{tabular}


Table 1 (continued)

\begin{tabular}{|c|c|}
\hline $\mathrm{Mg}$ & $\begin{array}{l}\text { Fructose 1,6-bisphosphatase (Shaul, 2002) } \\
\text { RuBisCO (Shaul, 2002, Kucera et al., 2008) } \\
\text { Sedoheptulose 1,7-bisphosphatase (Shaul, 2002) }\end{array}$ \\
\hline $\mathrm{Mn}$ & Malic enzyme (Takeuchi et al., 2000) \\
\hline $\mathrm{Zn}$ & $\begin{array}{l}\text { Carbonic anhydrase (Randall and Bouma, 1973) } \\
\text { Zn-protease degrading ribulose bisphosphate carboxylase oxygenase (Bushnell et al., } \\
\text { 1993) }\end{array}$ \\
\hline \multicolumn{2}{|c|}{ Antioxidant system } \\
\hline $\mathrm{Cu}$ & $\begin{array}{l}\mathrm{Cu} / \mathrm{Zn} \text {-superoxide dismutase (Grace, 1990) } \\
\text { Metallochaperone for } \mathrm{Cu} / \mathrm{Zn} \text { superoxide dismutase (Puig et al., 2007a) }\end{array}$ \\
\hline $\mathrm{Fe}$ & $\begin{array}{l}\text { Ascorbate peroxidase (Raven et al., 1999) } \\
\text { Fe-superoxide dismutase (Allen, 1995) }\end{array}$ \\
\hline $\mathrm{Mg}$ & Glutathione synthetase (Shaul, 2002) \\
\hline $\mathrm{Mn}$ & Mn-superoxide dismutase (Grace, 1990) \\
\hline $\mathrm{Zn}$ & $\mathrm{Cu} / \mathrm{Zn}$-superoxide dismutase (Grace, 1990) \\
\hline \multicolumn{2}{|c|}{ Sulfur metabolism } \\
\hline $\mathrm{Fe}$ & $\begin{array}{l}\text { Adenosine-5-phosphate reductase (Duy et al., 2007) } \\
\text { Sirohydrochlorin ferrochelatase (Duy et al., 2007) } \\
\text { Sulfite reductase (Duy et al., 2007) }\end{array}$ \\
\hline \multicolumn{2}{|c|}{ Nitrogen metabolism } \\
\hline $\mathrm{Fe}$ & $\begin{array}{l}\text { Amidophosphoribosyltransferase (Duy et al., 2007) } \\
\text { Glutamine-2-oxo-glutarate amido transferase (Duy et al., 2007) } \\
\text { NADH-dependent glutamine-2-oxo-glutarate amido transferase (Duy et al., 2007) } \\
\text { Nitrite reductase (Briat and Vert, 2004) } \\
\text { Sirohydrochlorin ferrochelatase (Duy et al., 2007) }\end{array}$ \\
\hline $\mathrm{Mg}$ & Glutamine synthetase (O’Neal and Joy, 1974) \\
\hline
\end{tabular}


Table 1 (continued)

\begin{tabular}{|l|l|}
\hline \multicolumn{2}{|l|}{ Basic metabolism } \\
\hline Zn & $\begin{array}{l}\text { Tic55 (Duy et al., 2007) } \\
\text { Chloroplast processing enzyme (VanderVere et al., 1995) } \\
\text { Enzymes involved in RNA editing (Hänsch and Mendel, 2009) }\end{array}$ \\
& $\begin{array}{l}\text { Metalloendopeptidase (Moberg et al., 2003) } \\
\text { Stromal processing peptidase (Hänsch and Mendel, 2009) } \\
\text { Zn-finger domains (e.g. Sasaki et al., 1989) }\end{array}$ \\
\hline
\end{tabular}

Metals move into the root both via the apoplasm and symplasm pathways (reviewed by Grusak et al. 1999). At the endodermis, all ions to be transported must enter the stele via the symplastic route by metal transporters located in the plasma membranes of endodermis cells. However, apoplastic flow at sites of lateral root emergence may occur and the Casparian bands do not represent a perfect barrier, as is usually thought (Ranathunge et al. 2005). Once within the stele, the ions are unloaded into the xylem vessels. They are transported toward the shoot as chelates of organic ligands (reviewed by Grusak et al. 1999; Fodor 2006; Haydon and Cobbett 2007; Puig et al. 2007a; Yruela 2009). Once the solutes have reached an organ, for example a leaf, the chelates travel in general through the apoplasm to the target cell (reviewed by Leigh and Tomos 1993; Grusak et al. 1999).

3.3 Metals can also enter the plant through the aboveground organs

In industrial areas or along heavily used roads (Wu et al. 2009), metals such as $\mathrm{Cd}, \mathrm{Hg}$, or $\mathrm{Pb}$ can be present in the air and enter into the plant through its aerial parts such as leaves (e.g., Nabulo et al. 2006; Sharma et al. 2008a, b), inflorescences (e.g., Peris et al. 2007), and fruits (e.g., Bi et al. 2006; Pandey and Pandey 2009). The metals can be absorbed through the cuticle and the epidermis during rainfalls or with dew formation. In these cases, the metals enter probably by stomata or ectodesmata and then move in the apoplasm of the organs (reviewed by Marschner 1995). Despite the fact that there are several data on metal deposition on crops (e.g., palak: Sharma et al. 2008a, b; cabbage: Sharma et al. 2008b; maize: Bi et al. 2006; red spinach: Pandey and Pandey 2009; artichoke, lettuce, and
Swiss chard: Peris et al. 2007; spinach, amaranth, and eggplant: Pandey and Pandey 2009), there is almost no information about the mobilization and transport processes of airborne pollutants inside higher plants.

In general, a large proportion of the metals present in excess in the soil is retained in the roots (e.g., Kawachi et al. 2009); however, in polluted areas, often considerable amounts of metals get transported to the shoots via the xylem. In addition, airborne pollutants may also increase metal concentration in aerial plant organs, and as a consequence, the probability of toxic or excess metals entering the chloroplasts increases.

\subsection{Chloroplasts as metal targets}

Despite the obvious roles of metals in plastid metabolism (Table 1), metal import mechanisms are not completely understood. Several transporters have been identified in plastid metal uptake and export (Fig. 1; reviewed by Weber et al. 2005; Spetea and Schoefs 2011). As the question marks indicate it in Fig. 1, the metal specificity, the direction of transport, and plastid localization are not yet completely determined for every metal transporter in vivo. Sometimes only the ion fluxes have been measured, but the protein has not been characterized in detail, as in the case of a thylakoidlocated $\mathrm{Ca}^{2+} / \mathrm{H}^{+}$antiporter directing $\mathrm{Ca}$ influx into the lumen (Ettinger et al. 1999, not shown in Fig. 1). Note that the nonphysiological ions such as $\mathrm{Cd}$ can be transported into the plastids using transporters of other essential metals (Fig. 1).

Metal transporters located in the chloroplast belong to the same metal transporter families found in other cell compartments. For instance, the protein HMA8/PAA2, located in the thylakoid membrane and transporting $\mathrm{Cu}$ into the thylakoid lumen, has homologues in the chloroplast envelope (HMA6/PAA1) in the tonoplast (e.g., Morel et al. 
2009) and in the plasma membrane (reviewed by Palmgren and Harper 1999; Yruela 2009).

Although some data are available about plastidial metal transporters, several questions still need to be elucidated about the uptake and the trafficking of metals into and within chloroplasts. However, it is clear that similarly to transporters present in other cellular compartments, often the carriers are not metal-specific; therefore, different metals may compete for them.

\subsection{Cross talk between different metals}

Nearly all studies on metal excess or deficiency have dealt with the effect of single elements, but such studies usually do not reflect a real situation in agriculture, or the critical response levels in nature. Actually, whenever a land becomes contaminated with metals, often two or more elements are in excess simultaneously and may compete for transporters (reviewed by Manthey et al. 1994). For instance, $\mathrm{P}_{1 \mathrm{~B}}$-type heavy metal ATPases are involved in the transport of a range of essential and potentially toxic metals (i.e., $\mathrm{Cu}, \mathrm{Zn}, \mathrm{Cd}, \mathrm{Pb}$ ) across cell membranes or other membranes (reviewed by Yruela 2009). This way, $\mathrm{Zn}$ competes with its toxic analogue, $\mathrm{Cd}$, for these transporters (Fig. 1). The consequence of such metal competition can be the deficiency of essential elements in chloroplasts. Therefore, the addition of the deficient metal often alleviates the toxic effects of the metal in excess (e.g., $\mathrm{Ca}$ in the case of excess $\mathrm{Al}$ : Guo et al. 2006; excess $\mathrm{Cd}$ : Wang and Song 2009; or excess Ni: Ouzounidou et al. 2006; Fe in the case of excess Cd: Siedlecka and Krupa 1996; Solti et al. 2008; $\mathrm{Zn}$ in the case of excess Cd: Zhao et al. 2005; Aravind and Prasad 2004; Podar et al. 2004). Interestingly, sometimes, a small amount of non-essential metal can be beneficial for the plant due to improvement of ion balance; for example, a low $\mathrm{Cr}$ level improves $\mathrm{Fe} / \mathrm{Mn}$ ratio in $\mathrm{Fe}$ deficient bean chloroplasts (Poschenrieder et al. 1991).

Cross talk between two or more essential elements also happens. For instance, $\mathrm{Zn}$ in high excess causes $\mathrm{Cu}$ and $\mathrm{Fe}$ deficiency (sugar beet: Sagardoy et al. 2009; rapeseed: Wang et al. 2009) and interference with $\mathrm{P}, \mathrm{Mg}, \mathrm{K}$, and Mn uptake (reviewed by Broadley et al. 2007). Ni excess can trigger decreased micronutrient levels $(\mathrm{Ca}, \mathrm{Mg}, \mathrm{Fe}, \mathrm{K}$; wheat: Ouzounidou et al. 2006), Fe deficiency (cabbage: Pandey and Sharma 2002), and K deficiency (pea: Gabbrielli et al. 1999) and hinder the transport of $\mathrm{K}$ and $\mathrm{Zn}$ (cucumber: Varga et al. 1999). On the other hand, $\mathrm{Mg}$ and $\mathrm{Ca}$ excess inhibits Ni uptake (reviewed by Chen et al. 2009). Excess $\mathrm{Cu}$ induces chlorosis (i.e., yellowing of the leaves due to decreased chlorophyll content), probably through a competitive interaction with $\mathrm{Fe}$ and or Mn uptake and/or transportation (reviewed by Yruela 2009), but competitive interactions of $\mathrm{Cu}$ with $\mathrm{Mg}, \mathrm{Mn}, \mathrm{Ni}$, and $\mathrm{Ca}$ have been also observed (reviewed by Barón et al. 1995; Chen et al. 2009).
It is clear from many studies that unbalanced soil metal concentrations can be reflected also in the plants. Either some essential elements are lacking and/or metals are in excess because the essential or non-essential metal(s) present in excess outcompete(s) the (other) essential metals from the uptake and transport mechanisms.

\section{Impact of metal deficiency}

In several agricultural fields, nutrient deficiency limits crop production (reviewed by Guerinot 2000). The metals, which are most likely to give rise to deficiency problems in plants, are $\mathrm{Cu}, \mathrm{Fe}, \mathrm{Mn}, \mathrm{Mo}$, and $\mathrm{Zn}$ (reviewed by Alloway 1995). When the deficiency is very strong, plants might be unable to compensate it and their use as human food might contribute to malnutrition. Below, we briefly discuss symptoms of metal deficiency on the metabolic, microscopic, and macroscopic levels with emphasis on chloroplasts.

\subsection{Molecular and metabolic alterations in chloroplasts}

Optimal concentrations of essential metals are needed for normal plastid ultrastructure, homeostasis, and functioning (for details, see Table 1 and Section 2). Chl biosynthesis requires several metals (Table 1); therefore, decreased $\mathrm{Chl}$ content is a general symptom of essential metal deficiency (e.g., Thoiron et al. 1997; Misra et al. 2006; Duy et al. 2007; Mahmoudi et al. 2007; Timperio et al. 2007; reviewed by Myśliwa-Kurdziel and Strzałka 2002). Electron transport efficiency (e.g., Droppa et al. 1984; Baszyński et al. 1978; reviewed by Maksymiec 1997) and $\mathrm{CO}_{2}$ fixation (e.g., Srivastava et al. 1997; Siedlecka and Krupa 1996; reviewed by Myśliwa-Kurdziel et al. 2002) also decrease as several enzymes or proteins involved in these processes require essential metals (Table 1). At the same time, oxidative stress is increased (e.g., under $\mathrm{Zn}, \mathrm{Mn}, \mathrm{Fe}$, $\mathrm{Cu}, \mathrm{B}, \mathrm{Mg}$, and $\mathrm{K}$ deficiency; Yu et al. 1999; reviewed by Cakmak 2000), which can be also explained partially by the fact that important components of reactive oxygenscavenging systems of plastids are metalloenzymes (e.g., $\mathrm{Cu}$-, $\mathrm{Zn}$-, Fe-containing superoxide dismutases). Lipids are also often affected by metal deficiency (e.g., Zn: reviewed by Cakmak 2000; Cu: reviewed by Barón et al. 1995).

Disturbances in stomatal conductance and water status are often reported for metal-deficient plants (e.g., Zn: Khan et al. 2004). Stomata opening requires ionic currents and special ion balance, including $\mathrm{K}, \mathrm{Ca}$, and $\mathrm{Mg}$ (reviewed by Shaul 2002; Maathuis 2009). As a consequence, deficiency or unbalanced $\mathrm{K}, \mathrm{Ca}$, and $\mathrm{Mg}$ concentrations lead to disturbances in the respiration and the transpiration (water homeostasis and mineral nutrition) of plants. Reduced $\mathrm{CO}_{2}$ 
uptake resulting from stomata closing inhibits the dark phase of photosynthesis and, this way, indirectly decreases crop productivity. All these observations are consistent with data of Table 1 and indicate profound alterations in plastid functions upon metal deficiency.

\subsection{Ultrastructural alterations of chloroplasts}

Metal-deficient conditions trigger ultrastructural changes in plastids (Table 2). The organelles are sometimes less abundant and smaller than in non-deficient plants. They have essentially disorganized thylakoid membranes, dismantled grana, and swollen intrathylakoidal space. An increase in the number and the size of plastoglobuli (spherical bodies that contain lipids, carotenoids, plastoquinone, and proteins) is also often observed.

Interestingly, the profound ultrastructural alterations observed in chloroplasts under different metal deficiencies are quite similar. This indicates that any disturbance in plastid ion homeostasis has drastic consequences on chloroplast structure and function and, this way, also on plant productivity.

\subsection{Alterations on the level of the entire plant}

Nutrient deficiency symptoms are usually expressed as reduced growth and altered physiology. When $\mathrm{Cu}, \mathrm{Fe}$, or $\mathrm{Zn}$ deficiency occurs, the root architecture is modified in order to allow an increase in the nutrient uptake and retention (reviewed by Wintz et al. 2002; Schmidt 2003; Puig et al. 2007a; Walker and Connolly 2008; Pilon et al. 2009). The interactions within the rhizosphere may also be altered (e.g., Rengel 1997; reviewed by Kidd et al. 2009). Another symptom is chlorosis accompanied by reduced photosynthetic activity leading to decreased biomass (e.g., Cu deficiency: reviewed by Maksymiec 1997; Fe deficiency: Timperio et al. 2007; Mn deficiency: Henriques 2004; Zn deficiency: Chen et al. 2008). Metal deficiency response of plants involves (1) increased expression and regulation of the uptake systems, (2) prioritization of the use of metals in essential versus dispensable pathways by mobilizing them within the plant, and (3) substitution of metalloproteins with similar or overlapping functions (reviewed by Puig et al. 2007a).

\section{Impact of metal excess}

Atmospheric deposition, urban-industrial activities, and agricultural practices (e.g., use of agrochemical products and addition of organic amendments) are the main anthropogenic sources of heavy metals in agricultural soils (e.g., Mico et al. 2006; Wei and Yang 2010). Representing a serious threat to mankind, the effect of metals present in excess on whole plants and chloroplasts has been widely studied and will be summarized below.

\subsection{Molecular and metabolic alterations in chloroplasts}

In the case of metal excess, a decrease in photosynthetic activity is often observed and other metabolic pathways are also altered. Metals trigger not only an oxidative burst but also the synthesis of specific molecules able to trap them. When toxic metals cannot be completely removed, inactivated, sequestrated, or detoxificated, they impact various molecules and prevent them from functioning properly (Fig. 2). Metal excess may also induce changes in membrane rigidity, permeability, and stability (i.e., Pb: Stefanov et al. 1995, Hg: reviewed by Boening 2000). The following section describes these events in detail.

\subsubsection{Metal-induced oxidative burst}

When present in excess, metals are directly involved in the formation of toxic reactive oxygen species causing oxidative stress. To protect themselves, cells try to maintain metal levels in a very narrow range between deficiency and toxicity (reviewed by Wintz et al. 2002). When they do not succeed, the following processes can be observed.

Metal ions block the electron flow in photosystem II (PSII), leading to the formation of excited triplet chlorophyll $\left({ }^{3} \mathrm{Chl}^{*}\right)$ whose lifetime is long enough to react with a molecule of oxygen with triplet electronic configuration. During the interaction, chlorophyll returns to the ground state and oxygen in turn is changed into highly reactive singlet oxygen. Oxidative stress leads to an unbalance in the regeneration and removal of reactive oxygen species, including singlet oxygen $\left({ }^{1} \mathrm{O}_{2}\right)$, superoxide radical $\left(\mathrm{O}_{2}^{-\bullet}\right)$, hydrogen peroxide $\left(\mathrm{H}_{2} \mathrm{O}_{2}\right)$, and the most damaging and reactive hydroxyl radical $\left(\mathrm{OH}^{\bullet}\right)$ which can lead to further lipid peroxidation and can damage membranes, proteins, and nucleic acids, leading to altered membrane fluidity, loss of enzyme functioning, and genomic damage (reviewed by Kucera et al. 2008). Induction of free radicals and reactive oxygen species by metals is very well documented and might be responsible for membrane injuries and some of the ultrastructural changes observed under metal stress (e.g., Babu et al. 2001; Zhang et al. 2005; RodríguezSerrano et al. 2009; reviewed by Sharma and Dietz 2009). The photooxidation risk is even increased by the inhibition of some photoprotective mechanisms such as the xanthophyll cycle (Bertrand et al. 2001).

Some metals such as $\mathrm{Fe}$ (Gallego et al. 1996) and $\mathrm{Cu}$ (Drazkiewicz et al. 2004; reviewed by Yruela 2009) induce reactive oxygen species directly, while others are thought to induce them only indirectly (Cd: Gallego et al. 1996; Pál et al. 2007; Cr: Panda et al. 2003; Panda 2007; Hg: Cho and 
Table 2 Examples of alterations in chloroplast structure of crop plants caused by deficiency in essential metals

\begin{tabular}{|c|c|c|}
\hline Metal & Species & Chloroplast alterations (reference) \\
\hline $\mathrm{Ca}$ & $\begin{array}{l}\text { Maize } \\
\text { (Zea mays) }\end{array}$ & $\begin{array}{l}\text { Disruption of the envelope membrane, lower grana, increased } \\
\text { number and size of plastoglobuli (Hall et al., 1972) }\end{array}$ \\
\hline $\mathrm{Cu}$ & $\begin{array}{l}\text { Oat } \\
\text { (Avena sativa) }\end{array}$ & $\begin{array}{l}\text { Disintegration of thylakoid membranes, swollen intrathylakoidal } \\
\text { space (Baszyński et al., 1978) }\end{array}$ \\
\hline \multirow[t]{5}{*}{$\mathrm{Fe}$} & $\begin{array}{l}\text { Apple } \\
\text { (Malus domestica) }\end{array}$ & $\begin{array}{l}\text { Disorganized (dispersed) grana, reduced starch content, increased } \\
\text { number of plastoglobuli (Ji et al., 1984) }\end{array}$ \\
\hline & $\begin{array}{l}\text { Maize } \\
\text { (Zea mays) }\end{array}$ & $\begin{array}{l}\text { Swollen intrathylakoidal space, disorganized thylakoids, no } \\
\text { grana (Thoiron et al., 1997) }\end{array}$ \\
\hline & $\begin{array}{l}\text { Pecan } \\
\text { (Carya illinoinensis) }\end{array}$ & $\begin{array}{l}\text { Reduced internal membrane system, almost no grana, increased } \\
\text { starch content, increased number of plastoglobuli (Henriques, } \\
\text { 2003) }\end{array}$ \\
\hline & $\begin{array}{l}\text { Sugar beet } \\
\text { (Beta vulgaris) }\end{array}$ & $\begin{array}{l}\text { Small plastids, undeveloped, disorganized grana, clusters of } \\
\text { peripheral vesicles (Platt-Aloia et al., 1983) }\end{array}$ \\
\hline & $\begin{array}{l}\text { Tobacco } \\
\text { (Nicotiana tabacum) }\end{array}$ & $\begin{array}{l}\text { Unstacked and diffuse thylakoids, increased starch content, } \\
\text { unusual vesicles (Briat et al., 1999) }\end{array}$ \\
\hline \multirow[t]{2}{*}{$\mathrm{K}$} & $\begin{array}{l}\text { Bean } \\
\text { (Phaseolus vulgaris) }\end{array}$ & Grana breakdown (Thomson and Weier, 1962) \\
\hline & $\begin{array}{l}\text { Maize } \\
\text { (Zea mays) }\end{array}$ & $\begin{array}{l}\text { No significant alterations, membranes lacking contrast (Hall et } \\
\text { al., 1972) }\end{array}$ \\
\hline \multirow[t]{2}{*}{$\mathrm{Mg}$} & $\begin{array}{l}\text { Bean } \\
\text { (Phaseolus vulgaris) }\end{array}$ & Disorganized grana (Thomson and Weier, 1962) \\
\hline & $\begin{array}{l}\text { Maize } \\
\text { (Zea mays) }\end{array}$ & $\begin{array}{l}\text { Reduced inner membranes, increased number and size of } \\
\text { plastoglobuli (Hall et al., 1972) }\end{array}$ \\
\hline
\end{tabular}

Park 2000; Mn: Lidon and Teixeira 2000a, b; Na: Mitsuya et al. 2000; Yamane et al. 2009; reviewed by Wang et al. 2003; Miyake et al. 2006; Ni: reviewed by Chen et al. 2009; Zn: Panda et al. 2003; reviewed by Sharma and Dietz 2009; Kawachi et al. 2009; Fig. 2).
Both metal deficiency (see Section 4.1) and metal excess trigger lipid peroxidation (e.g., Al: Giannakoula et al. 2008; Cd: Gallego et al. 1996; Sandalio et al. 2001; Djebali et al. 2005; Skórzyńska-Polit and Krupa 2006; Hg: Cho and Park 2000; excess Cu: Babu et al. 2001; excess Fe: Gallego et al. 
Table 2 (continued)

\begin{tabular}{|c|c|c|}
\hline \multirow[t]{4}{*}{$\mathrm{Mn}$} & $\begin{array}{l}\text { Lemon } \\
\text { (Citrus volkameriana) }\end{array}$ & $\begin{array}{l}\text { Reduced chloroplast size and starch size, few, slightly swollen } \\
\text { intrathylakoidal spaces (Papadakis et al., 2007) }\end{array}$ \\
\hline & $\begin{array}{l}\text { Pecan } \\
\text { (Carya illinoinensis) }\end{array}$ & $\begin{array}{l}\text { Decrease in chloroplast number, no apparent change in the } \\
\text { thylakoids (Henriques, 2003, 2004) }\end{array}$ \\
\hline & $\begin{array}{l}\text { Soybean } \\
\text { (Glycine } \max \text { ) }\end{array}$ & $\begin{array}{l}\text { Disruption of thylakoids and swollen intrathylakoidal space, } \\
\text { strong decrease in starch content, increased number of } \\
\text { plastoglobuli (Weiland et al., 1975, Izaguirre-Mayoral and } \\
\text { Sinclair, 2005) }\end{array}$ \\
\hline & $\begin{array}{l}\text { Spinach } \\
\text { (Spinacia oleracea) }\end{array}$ & $\begin{array}{l}\text { Disruption of thylakoids, swollen intrathylakoidal space in grana, } \\
\text { appearance of vesicles corresponding to swollen stromal } \\
\text { thylakoids (Mercer et al., 1962, Possingham et al., 1964) }\end{array}$ \\
\hline \multirow[t]{3}{*}{$\mathrm{Zn}$} & $\begin{array}{l}\text { Bean } \\
\text { (Phaseolus vulgaris) }\end{array}$ & Disturbed grana development (Thomson and Weier, 1962) \\
\hline & $\begin{array}{l}\text { Rice } \\
\text { (Oryza sativa) }\end{array}$ & $\begin{array}{l}\text { Swollen chloroplasts, disruption of the envelope membrane, } \\
\text { swollen intrathylakoidal space, decreased number of grana, } \\
\text { disorganization of the thylakoids, increased number of } \\
\text { plastoglobuli (Chen et al., 2008) }\end{array}$ \\
\hline & $\begin{array}{l}\text { Sugar beet } \\
\text { (Beta vulgaris) }\end{array}$ & $\begin{array}{l}\text { Premature senescence: disruption of thylakoids, unstacking of } \\
\text { grana, degeneration of stromal components (Henriques, 2001) }\end{array}$ \\
\hline
\end{tabular}

1996; Babu et al. 2001; excess Zn: Wang et al. 2009; reviewed by Poirier et al. 2008) and production of reactive oxygen species; therefore, we can conclude that metal unbalance is responsible for oxidative stress. This is not so surprising if we also consider that besides the direct effect of metals, several enzymes involved in the detoxification of reactive oxygen species contain different metals (e.g., $\mathrm{Cu}$, $\mathrm{Fe}$, and $\mathrm{Zn}$ in superoxide dismutases; Table 1) and their functioning is also disturbed under conditions with unbalanced metal concentrations.

\subsubsection{Synthesis of molecules trapping metals}

Chloroplasts have been reported not only as metabolic units that require metals in well-defined amounts for their proper functioning but also as possible compartments for the sequestration of excess metals. The storage of essential metals in chloroplasts in non-toxic form contributes to homeostasis and provides a reservoir for future requirements. For instance, excess $\mathrm{Fe}$ is stored as ferritin (Izaguirre-Mayoral and Sinclair 2005, 2009; reviewed by Briat et al. 1999). Interestingly, in transgenic plants overexpressing ferritin and grown under normal Fe supply, ultrastructural symptoms of $\mathrm{Fe}$-deficient chloroplasts were observed, indicating that ferritin is important in storing iron in a metabolically inactive form (reviewed by Briat et al. 1999 ) and thus preventing oxidative damage (Ravet et al. 2009; reviewed by Arosio and Levi 2002). Similarly, the role of a plastocyanin isoform as a $\mathrm{Cu}$ sink under excess $\mathrm{Cu}$ has been reported recently (reviewed by Abdel-Ghany 


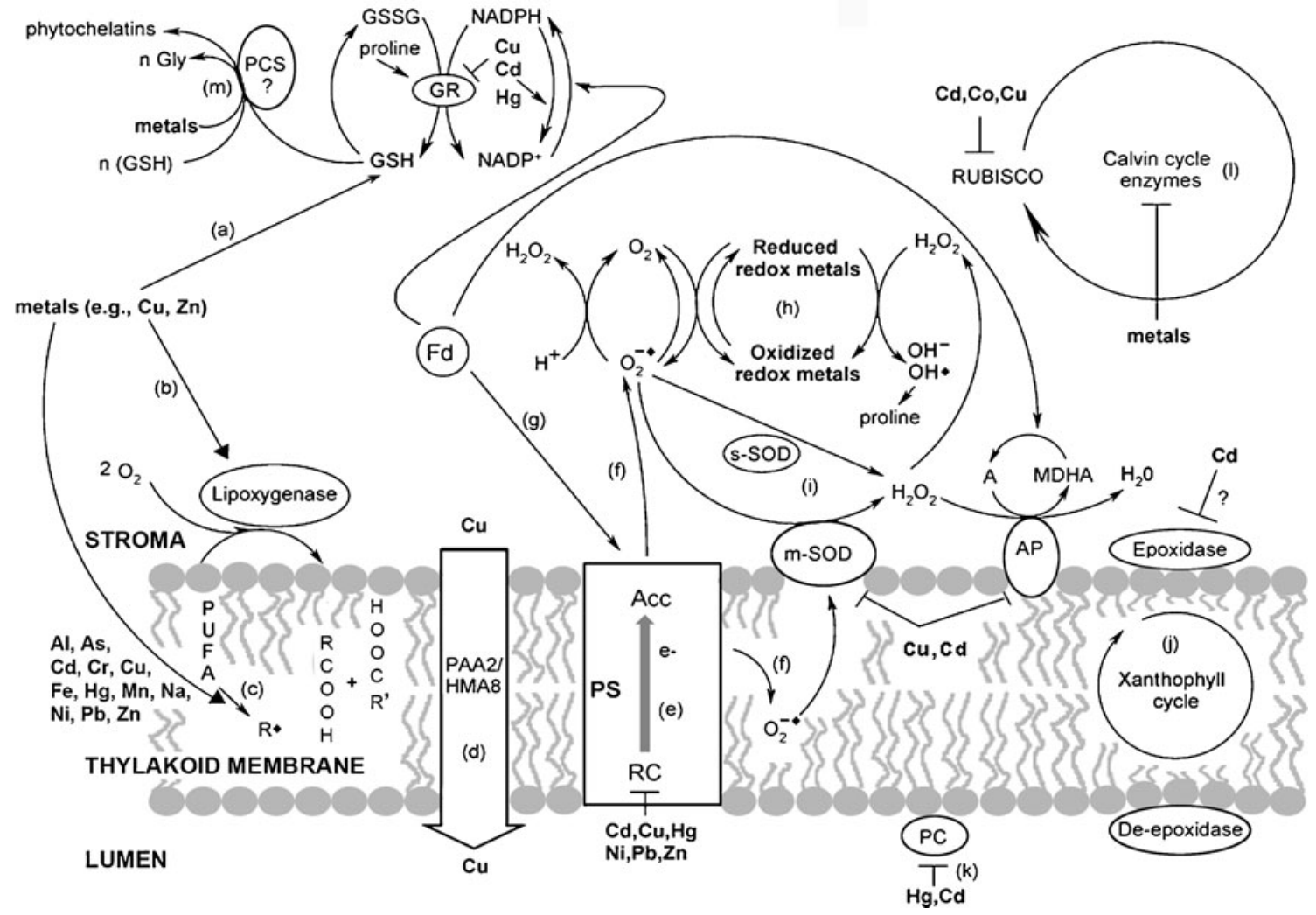

Fig. 2 Scheme summarizing most important chloroplast processes and components impacted by metal excess with emphasis on oxidative stress and defense reactions. a Depletion of sulfhydryl groups by metals on reduced glutathione $(G S H)$ regenerated by glutathione reductase $(G R)$ from its oxidized form $(G S S G)$. b Activation of lipoxygenase by metals. c Peroxidation of polyunsaturated fatty acids (PUFA) to free radicals $\left(\mathrm{R}^{\bullet}\right)$ and saturated fatty acids $\left(\mathrm{RCOOH}+\mathrm{R}^{\prime} \mathrm{COOH}\right)$ in membranous phospholipids. d $\mathrm{Cu}$ transporter PAA2/HMA8 directing $\mathrm{Cu}$ transport toward the lumen. e Electron transfer from the reaction center $(R C)$ to the acceptor $(A c c)$ of PSI or PSII. f Univalent oxygen reduction by PSII. g Electron transfer through ferredoxin $(\mathrm{Fd})$ and $\mathrm{NADP}^{+}$(specific to PSI). h Fenton and Haber-Weiss reactions: one-electron oxidoreductions performed by redox metals leading to hydroxyl radicals $\left(\mathrm{OH}^{\bullet}\right)$. i Spontaneous and/or superoxide dismutase $(S O D)$ catalyzed dispropor-

2009). Besides its function as an electron carrier (for which a small amount of plastocyanin is enough), plastocyanin seems to have a role in buffering excess $\mathrm{Cu}$ within the plastids and to contribute this way to intracellular tolerance of excess $\mathrm{Cu}$. Concerning excess $\mathrm{Na}^{+}$, recent studies on mutants lacking $\mathrm{CHX} 23$ (an envelope located $\mathrm{Na}^{+}\left(\mathrm{K}^{+}\right) / \mathrm{H}^{+}$ ATPase) suggest that plastidial sequestration of excess $\mathrm{Na}^{+}$ may be important in salt tolerance mechanisms in plants and can prevent phytotoxic effects of this element in the cytosol (Song et al. 2004a). These data outline the importance of plastids also in metal tolerance of plants grown in polluted areas and show that plants may need to synthesize specific proteins to store excess metals in a metabolically inactive form in the chloroplasts.

Phytochelatins also have an essential function in trapping metals present in excess. They are metal-complexing tionation of superoxides $\left(\mathrm{O}_{2}^{-\bullet}\right)$. Superoxide radicals generated by PSI and PSII are dismutated by the membrane-bound $\mathrm{m}$-SOD, and the formed hydrogen peroxide $\left(\mathrm{H}_{2} \mathrm{O}_{2}\right)$ is reduced to water by the thylakoidbound ascorbate peroxidase $(A P)$. Monodehydroascorbate $(M D H A)$ is reduced back to ascorbate $(A)$ by the photoreduced ferredoxin $(\mathrm{Fd})$. $\mathrm{O}_{2}^{-\bullet}$ radicals escaped from the thylakoid system are scavenged by a stromal s-SOD. j Xanthophyll cycle associated to the enzymes epoxidase and de-epoxidase, preventing superoxide formation at high light intensity. k Inactivation of plastocyanin $(P C)$ by non-essential metals after its release from the membrane or the release of its $\mathrm{Cu}$. I Inactivation of Calvin cycle enzymes. $\mathbf{m}$ Chelation of metals by phytochelatins either imported from the cytoplasm or synthesized through the activity of a putative phytochelatine synthetase (PCS). $\rightarrow$ activation by metals; $\uparrow$ inhibition by metals

peptides with a high proportion of Cys residues, a general structure of ( $\gamma$-Glu-Cys) $)_{2-11}$-Gly, and are generally known to function in the vacuolar sequestration of excess metals (reviewed by Cobbett 2000; Hall 2002). The occurrence of phytochelatins in the chloroplasts has been also reported under Cd stress; however, their origin and exact role still remains unclear (reviewed by Kucera et al. 2008). On the other hand, in transgenic plants expressing phytochelatin synthase in chloroplasts, the accumulation and tolerance of Cd was not changed, but As sensitivity of the plants increased (Picault et al. 2006).

Heat-shock proteins and chaperones may also be involved and related to plastid sequestration of metals and to the metal tolerance of plastids. Examples include the plant homologue of CCS, the yeast chaperone to $\mathrm{Cu} / \mathrm{Zn}$ superoxide dismutase, and some predicted Arabidopsis 
homologues of yeast ATX1 Cu chaperones (reviewed by Wintz and Vulpe 2002; Puig et al. 2007a). The encoded proteins possess a potential chloroplast-targeting sequence, suggesting that they are chloroplast proteins and most likely involved in the maturation of the chloroplast $\mathrm{Cu} / \mathrm{Zn}$ superoxide dismutase apoprotein, in the delivery of $\mathrm{Cu}$ to this protein, or in chloroplast transport mechanisms. The ATX1 family of $\mathrm{Cu}$ chaperones specifically delivers $\mathrm{Cu}$ to heavy metal P-type ATPases (Puig et al. 2007b), such as HMA1 located in the chloroplast envelope which can remove excess metals from plastids (Kawachi et al. 2009; Kim et al. 2009). This way, this chaperone may be involved in the detoxification of plastids or in the maintenance of plastid ion homeostasis. In addition, the CUTA protein, which binds $\mathrm{Cu}$ and localizes to the intermembrane space of chloroplast envelopes, has been proposed as a candidate for a $\mathrm{Cu}$ metallochaperone (reviewed by Puig et al. 2007a).

Plastids possess a variety of mechanisms to cope with metals in excess; however, in the case of heavily polluted areas and plants, these strategies may also be not satisfactory and plastid metabolism can be altered.

\subsubsection{Molecules impacted by metals}

When present in excess, metals may interact directly or indirectly with plastid lipids, pigments, proteins, and important cofactors required for photosynthesis. They may replace another functional metal within enzymes or in key molecules such as chlorophyll. In this part, we try to summarize these interactions of excess metals.

Lipids The observed changes in membrane structure might at least be partially due to membrane lipid alterations in metal exposed plants (reviewed by Devi and Prasad 2006). Excess metals influence the lipid composition, the saturation, or even the chain length of the fatty acids of membrane lipids (e.g., Cd-pepper: Jemal et al. 2000; tomato: Djebali et al. 2005; Ben Ammar et al. 2007, maize: Pál et al. 2007; $\mathrm{Cu} —$ spinach: Maksymiec et al. 1992; runner bean: Maksymiec et al. 1994; Na—spinach: Stefanov et al. 1995; $\mathrm{Pb}$ - spinach: Stefanov et al. 1995). The excess of several non-essential metals (e.g., Cd: Skórzyńska et al. 1991; Skórzyńska and Baszyński 1993; SkórzyńskaPolit and Baszyński 1997; Skórzyńska-Polit et al. 1998; Jemal et al. 2000; Nouairi et al. 2006; Na: and Pb: Stefanov et al. 1995), but also excess micronutrients (e.g., $\mathrm{Cu}$ : Maksymiec et al. 1992; Quartacci et al. 2000; Mn: Lidon et al. 2004), decrease the monogalactosyldiacylglycerol (MGDG) content. As MGDG and digalactosyldiacylglycerol ratios influence membrane curvature, the changes in their ratios can explain the observed alterations in grana stacking and/or grana-to-stroma thylakoid ratios under metal stress (Table 3). Similarly, the swollen intrathylakoi- dal space has been related to decreased MGDG levels caused by increased galactolipase activity (Skórzyńska et al. 1991).

MGDG is not only an important structural element of the thylakoid membranes but is also required for the proper functioning of photosynthesis (PSII complexes); therefore, changes in this lipid fraction may have a detrimental effect on thylakoid functions and the total photosynthetic efficiency of plants. Similarly, the metal-induced changes in fatty acid desaturation influence the membrane fluidity (Quartacci et al. 2000), which in turn leads to altered membrane physiological functions and, particularly, influences the ionic permeability of the thylakoid membranes (reviewed by Devi and Prasad 2006). Metal-induced lipid peroxidation can lead to the release of pigment-protein complexes, oxygen evolving complex, and plastocyanin, blocking further electron transport (reviewed by Siedlecka and Krupa 1996, 1999; Pál et al. 2006).

Lipids and, as a consequence, all membrane-related processes of chloroplasts are sensitive to metal excess, and their alterations may be reflected also at the ultrastructural level as disturbed chloroplast structure.

Pigments The inhibitory effect of excess metals on chlorophyll and carotenoid biosynthesis (reviewed by MyśliwaKurdziel and Strzałka 2002; Bertrand and Poirier 2005; Schoefs 2005) and on photosynthesis (reviewed by Myśliwa-Kurdziel et al. 2004; Sárvári 2005; Fodor 2006; Briat et al. 2007) are reviewed elsewhere in more detail.

$\mathrm{Cr}(\mathrm{VI}), \mathrm{Fe}(\mathrm{III})$, and $\mathrm{Hg}(\mathrm{II})$ have been shown to directly inhibit one of the key enzymes of chlorophyll biosynthesis, NADPH:protochlorophyllide oxidoreductase in vitro (Hg: Lenti et al. 2002; Solymosi et al. 2004; Cr and Fe: Myśliwa-Kurdziel and Strzałka 2005). $\mathrm{Cd}$ also inhibits chlorophyll biosynthesis directly through ALA dehydratase and NADPH:protochlorophyllide reductase in vitro (Stobart et al. 1985; Böddi et al. 1995; Myśliwa-Kurdziel and Strzałka 2005).

Loss of chlorophyll (e.g., chlorophyll $b$ in the case of $\mathrm{Zn}$ and Cd stress: Ebbs and Uchil 2008) and decreased levels of carotenoids (e.g., Cd: Drazkiewicz and Baszyński 2005; excess Cu: Baszyński et al. 1988; reviewed by MyśliwaKurdziel and Strzałka 2002) are often reported under metal stress and can lead to impaired photosynthetic activities. Some authors suggest that metals interfere with carotenoid biosynthesis on the level of phytoene or in terpenoid biosynthesis prior to the formation of geranyl-geranyl pyrophosphate (reviewed by Barón et al. 1995), the latter being also needed for the phytol chain in chlorophyll molecules.

Besides the direct inhibition of pigment biosynthetic processes of plastids, metals may induce directly or indirectly the function loss or the oxidative breakdown of 
Table 3 Examples of alterations in chloroplast structure of crops caused by excess of metals

\begin{tabular}{|c|c|c|}
\hline Metal & Species & Chloroplast alterations (Reference) \\
\hline $\begin{array}{l}\mathrm{Al} \\
(\mathrm{ne})\end{array}$ & $\begin{array}{l}\text { Wheatgrass } \\
\text { (Thinopyrum } \\
\text { bessarabicum) }\end{array}$ & $\begin{array}{l}\text { Swelling and distension of the chloroplast, grana arranged in } \\
\text { bow-like lines (Moustakas et al., 1996, 1997) }\end{array}$ \\
\hline \multirow[t]{5}{*}{ (ne) } & $\begin{array}{l}\text { Common bean } \\
\text { (Phaseolus vulgaris) }\end{array}$ & $\begin{array}{l}\text { Sometimes disruption of the envelopes, disordered position } \\
\text { and stacking of thylakoids, increased number and size of } \\
\text { plastoglobuli (Barceló et al., 1988) }\end{array}$ \\
\hline & $\begin{array}{l}\text { Oilseed rape } \\
\text { (Brassica napus) }\end{array}$ & $\begin{array}{l}\text { Reduced number of chloroplasts, slightly reduced grana size, } \\
\text { slightly reduced number of plastoglobuli, but no striking } \\
\text { ultrastructural effect (Baryla et al., 2001, Carrier et al., 2003) }\end{array}$ \\
\hline & $\begin{array}{l}\text { Pea } \\
\text { (Pisum sativum) }\end{array}$ & $\begin{array}{l}\text { Reduced number of chloroplasts, senescence (disorganization } \\
\text { of grana, increased starch content, increased number and size } \\
\text { of plastoglobuli) (McCarthy et al., 2001, Sandalio et al., 2001) }\end{array}$ \\
\hline & $\begin{array}{l}\text { Tomato } \\
\text { (Lycopersicon } \\
\text { esculentum) }\end{array}$ & $\begin{array}{l}\text { - Swollen intrathylakoidal space, senescence (disorganization } \\
\text { of grana, increased number and size of plastoglobuli) } \\
\text { (Baszyński et al., 1980) } \\
\text { - Disturbed chloroplast shape, swollen intrathylakoidal space } \\
\text { (Djebali et al., 2005) }\end{array}$ \\
\hline & $\begin{array}{l}\text { Wheat } \\
\text { (Triticum aestivum) }\end{array}$ & $\begin{array}{l}\text { Senescence (disturbed thylakoid shape, swollen } \\
\text { intrathylakoidal space), regularly spotted bodies (Ouzounidou } \\
\text { et al., 1997) }\end{array}$ \\
\hline $\begin{array}{l}\mathrm{Cr}(\mathrm{III}) \\
\text { (ne) }\end{array}$ & $\begin{array}{l}\text { Common bean } \\
\text { (Phaseolus vulgaris) }\end{array}$ & No ultrastructural effect (Poschenrieder et al., 1991) \\
\hline $\begin{array}{l}\mathrm{Cr}(\mathrm{VI}) \\
\text { (ne) }\end{array}$ & $\begin{array}{l}\text { Common bean } \\
\text { (Phaseolus vulgaris) }\end{array}$ & $\begin{array}{l}\text { Slightly distorted (rounded) chloroplast shape, decrease in } \\
\text { grana thylakoids, swollen intrathylakoidal space (Vázquez et } \\
\text { al., 1987) }\end{array}$ \\
\hline $\mathrm{Cu}$ & $\begin{array}{l}\text { Durum wheat } \\
\text { (Triticum durum) }\end{array}$ & $\begin{array}{l}\text { - Swollen intrathylakoidal space, regularly spotted bodies } \\
\text { (Ciscato et al., 1997) } \\
\text { - Swollen intrathylakoidal space (Quartacci et al., 2000) }\end{array}$ \\
\hline
\end{tabular}


Table 3 (continued)

\begin{tabular}{|c|c|c|}
\hline & $\begin{array}{l}\text { Oregano } \\
\text { (Origanum vulgare) }\end{array}$ & $\begin{array}{l}\text { Reduced number and size of chloroplasts, dilated envelope, no } \\
\text { starch, increased size of plastoglobuli (Panou-Filotheou et al., } \\
\text { 2001) }\end{array}$ \\
\hline & $\begin{array}{l}\text { Runner bean } \\
\text { (Phaseolus } \\
\text { coccineus) }\end{array}$ & $\begin{array}{l}\text { Senescence (disorganization of chloroplast structure, } \\
\text { disturbances in stroma lamellae) (Maksymiec et al., 1995) }\end{array}$ \\
\hline & $\begin{array}{l}\text { Soybean } \\
\text { (Glycine max) }\end{array}$ & $\begin{array}{l}\text { Smaller, but more numerous chloroplasts with rounded shape, } \\
\text { denser structured internal membranes (increased grana size and } \\
\text { stacking) (Bernal et al., 2006) }\end{array}$ \\
\hline & $\begin{array}{l}\text { Spinach } \\
(\text { Spinacia oleracea })\end{array}$ & $\begin{array}{l}\text { Degradation of grana stacks and stroma lamellae, slightly } \\
\text { swollen intrathylakoidal space, increased number and size of } \\
\text { plastoglobuli (Baszyński et al., 1988) }\end{array}$ \\
\hline & $\begin{array}{l}\text { Wheat } \\
\text { (Triticum aestivum) }\end{array}$ & $\begin{array}{l}\text { Reduced number and size of chloroplasts, less developed } \\
\text { internal membrane system, impaired grana formation, } \\
\text { decreased starch content, decreased number of plastoglobuli } \\
\text { (Eleftheriou and Karataglis, 1989) }\end{array}$ \\
\hline $\mathrm{Fe}$ & $\begin{array}{l}\text { Soybean } \\
\text { (Glycine max) }\end{array}$ & Appearance of ferritin (Izaguirre-Mayoral and Sinclair, 2005) \\
\hline $\mathrm{Mn}$ & $\begin{array}{l}\text { Lemon } \\
\text { (Citrus } \\
\text { volkameriana) }\end{array}$ & $\begin{array}{l}\text { More rounded chloroplasts with slightly increased size, } \\
\text { reduced number of grana, increased starch content, increased } \\
\text { number and size of plastoglobuli, increased depositions of } \\
\text { dark-materials in thylakoids (Papadakis et al., 2007) }\end{array}$ \\
\hline & $\begin{array}{l}\text { Maple } \\
\text { (Acer saccharum) }\end{array}$ & $\begin{array}{l}\text { Discrete electron-dense areas in chloroplast thylakoid } \\
\text { membranes, increased starch content (McQuattie and Schier, } \\
\text { 2000) }\end{array}$ \\
\hline & $\begin{array}{l}\text { Rice } \\
\text { (Oryza sativa) }\end{array}$ & $\begin{array}{l}\text { Swollen intrathylakoidal space, increased number and size of } \\
\text { plastoglobuli (Lidon and Teixeira, 2000a) }\end{array}$ \\
\hline $\begin{array}{l}\mathrm{Na} \\
(\mathrm{ne})\end{array}$ & $\begin{array}{l}\text { Alfalfa } \\
\text { (Medicago sativa) }\end{array}$ & $\begin{array}{l}\text { Swollen intrathylakoidal space, increased number of } \\
\text { plastoglobuli in cotyledonal chloroplasts (Baranova et al., } \\
2007 \text { ) }\end{array}$ \\
\hline
\end{tabular}


Table 3 (continued)

\begin{tabular}{|c|c|c|}
\hline & $\begin{array}{l}\text { Maize } \\
(\text { Zea mays })\end{array}$ & $\begin{array}{l}\text { Swollen intrathylakoidal space, increased number and size of } \\
\text { plastoglobuli (Hasan et al., 2005) }\end{array}$ \\
\hline & $\begin{array}{l}\text { Pea } \\
\text { (Pisum sativum) }\end{array}$ & Increased number of plastoglobuli (Hernandez et al., 1995) \\
\hline & $\begin{array}{l}\text { Rice } \\
\text { (Oryza sativa) }\end{array}$ & $\begin{array}{l}\text { Swollen intrathylakoidal space, with increasing concentrations: } \\
\text { swelling of chloroplasts, disruption of the envelope membrane, } \\
\text { increased number and size of plastoglobuli (Rahman et al., } \\
\text { 2000, Mitsuya et al., 2003, Yamane et al., 2003, 2004, 2008, } \\
\text { 2009) }\end{array}$ \\
\hline & $\begin{array}{l}\text { Sweet potato } \\
\text { (Ipomoea batatas) }\end{array}$ & $\begin{array}{l}\text { Swollen intrathylakoidal space, degradation of thylakoid } \\
\text { membranes (Mitsuya et al., 2000) }\end{array}$ \\
\hline & $\begin{array}{l}\text { Tomato } \\
\text { (Lycopersicon } \\
\text { esculentum) }\end{array}$ & $\begin{array}{l}\text { - Genotype-specific differences in chloroplast shape (more } \\
\text { rounded or flatter) and number, in starch and plastoglobuli } \\
\text { content, less organized internal membrane system (Sam et al., } \\
2003 \text { ) } \\
\text { - no grana and thylakoids (Khavari-Nejad and Mostofi, 1998) }\end{array}$ \\
\hline & $\begin{array}{l}\text { Wheat } \\
\text { (Triticum aestivum) }\end{array}$ & $\begin{array}{l}\text { Swollen intrathylakoidal space, accumulation of starch } \\
\text { (Salama et al., 1994) }\end{array}$ \\
\hline $\mathrm{Ni}$ & $\begin{array}{l}\text { Cabbage } \\
\text { (Brassica oleracea) }\end{array}$ & $\begin{array}{l}\text { Reduced number of grana, alterations in size and shape of } \\
\text { thylakoids, swollen intrathylakoidal space, increased starch } \\
\text { content, increased size of plastoglobuli (Molas, 1997, 2002) }\end{array}$ \\
\hline (ne) & $\begin{array}{l}\text { Barley } \\
\text { (Hordeum vulgare) }\end{array}$ & $\begin{array}{l}\text { Fewer, but more elongated grana, increased starch content, increased } \\
\text { number and size of plastoglobuli, dark deposits at grana margins, regularly } \\
\text { spotted bodies (Woźny et al., 1995) }\end{array}$ \\
\hline & $\begin{array}{l}\text { Pea } \\
\text { (Pisum sativum) }\end{array}$ & $\begin{array}{l}\text { Sometimes disruption of the envelopes, dark deposits at the grana margins } \\
\text { (Sabnis et al., 1969) }\end{array}$ \\
\hline & $\begin{array}{l}\text { Soybean } \\
\text { (Glycine max) }\end{array}$ & $\begin{array}{l}\text { Disruption of the envelope, reduced lamellar system, disorganization of } \\
\text { thylakoids (Weryszko-Chmielewska and Chwil, 2005) }\end{array}$ \\
\hline $\begin{array}{l}{ }^{99} \mathrm{Tc} \\
\text { (ne) }\end{array}$ & $\begin{array}{l}\text { Common bean } \\
\text { (Phaseolus vulgaris) }\end{array}$ & $\begin{array}{l}\text { Swollen chloroplasts, disintegration of the thylakoid system, } \\
\text { decreased starch content (Vázquez et al., 1990) }\end{array}$ \\
\hline
\end{tabular}


Table 3 (continued)

\begin{tabular}{|l|l|l|l|}
\hline $\mathrm{Zn}$ & Pea & Disintegration of stromal thylakoids, with increasing \\
& (Pisum sativum $)$ & $\begin{array}{l}\text { concentrations: reduced number of grana, swollen } \\
\text { intrathylakoidal space, disappearance of starch, increased } \\
\text { number and size of plastoglobuli (Doncheva et al., 2001) }\end{array}$ \\
\end{tabular}

ne non-essential elements

pigments. For example, $\mathrm{Hg}$ has been shown to induce the loss of the central $\mathrm{Mg}$ from a chlorophyll precursor, resulting in non-functional pigments (Solymosi et al. 2004). Similarly, several metals (e.g., Cd, Hg, Pb, Cu, Zn, and $\mathrm{Ni}$ ) can replace $\mathrm{Mg}$ in chlorophylls, resulting in photosynthetically inactive molecules (Küpper et al. 1996, 1998, 2002, 2003). A primary site of $\mathrm{Cu}$ inhibition was identified on the antenna chlorophyll $a$ molecules of PSII (Lidon et al. 1993). Without antenna chlorophylls, photosynthesis is blocked.

Clearly, several data indicate that excess of either essential or non-essential metals can interact with photosynthetic pigments (chlorophylls and carotenoids) and inhibit their biosyntheses, which might be a reason for the observed decline in photosynthetic functions and pigments. However, most of these studies used very high (and this way often non-physiological and non-natural, agronomically not relevant) concentrations of the metals and/or did not work with intact plants but with different in vitro preparations. Therefore, the direct effect of excess metals is only theoretically proved in planta, but probably, other indirect interactions and impacts (e.g., changes of ion and water homeostasis, competition with essential metals) must also be considered and may be more probable in vivo.

Proteins One metal in excess may substitute another one in metalloproteins. For instance, $\mathrm{Hg}$ can substitute $\mathrm{Cu}$ in plastocyanin (cf. Radmer and Kok 1974), Co replaces $\mathrm{Mg}$ in ribulose-1,5-bisphosphate carboxylase oxygenase (RuBisCO) or $\mathrm{Zn}$ in transcription factors (reviewed by Poirier et al. 2008), and $\mathrm{Cd}$ replaces $\mathrm{Ca}$ in photosystem II reaction center, causing inhibition of PSII photoactivation (Skórzyńska and Baszyński 1993; Faller et al. 2005; reviewed by Kucera et al. 2008). Cd can replace $\mathrm{Zn}$ and $\mathrm{Ca}$ in metalloenzymes (reviewed by Clemens et al. 2009). The substitution of $\mathrm{Mn}$ by $\mathrm{Zn}$ or $\mathrm{Cd}$ leads to the inactivation of the oxygen evolving complex, and as a consequence, electron donation to PSII is inhibited (e.g., Baszyński et al. 1980; reviewed by Bertrand and Poirier 2005; Pál et al. 2006; Kucera et al. 2008).
$\mathrm{Hg}$ ions can directly interact with some sites in the photosynthetic electron transport chain situated in D1 and D2 proteins and with the Mn cluster in the oxygen-evolving complex (reviewed by Romanowska 2002). Al inhibits ATPase and hexokinase activity in chloroplasts (reviewed by Romanowska 2002). Each of these effects could be responsible individually or in combination for Al toxicity to photosynthesis, i.e., the decreased photosynthetic electron transport associated with photosystem I (PSI) and the reduced $\mathrm{CO}_{2}$ assimilation rates. Excess $\mathrm{Cu}$ also inhibits several polypeptides of PSII and PSI (e.g., Lidon and Henriques 1993; Maksymiec et al. 1994).

One of the most often reported direct toxic effects of metals on plastid proteins is attributed to the ability of some metals to bind to sulfhydryl, histidyl, and carboxyl groups of proteins, inducing therefore conformational changes, resulting often in inactivation or disturbed function $(\mathrm{Cd}, \mathrm{Pb}$, Hg: reviewed by Vallee and Ulmer 1972; Hg: Lenti et al. 2002; Solymosi et al. 2004; Cu: reviewed by Maksymiec 1997; Yruela 2009).

Metal-sensitive plant enzymes of $\mathrm{CO}_{2}$ fixation include RuBisCO (e.g., inhibited by Cd: Siedlecka and Krupa 1996, 1999; $\mathrm{Cu}$ excess: Lidon and Henriques 1991, 1993; Maksymiec et al. 1994), phosphoenolpyruvate carboxylase (Cd: reviewed by Siedlecka and Krupa 1996, 1999; Pál et al. 2006; Mg, Mn, Co, Fe, Cd: Nguyen et al. 1988), glyceraldehyde-3-phosphate dehydrogenase, 3phosphoglycerate kinase, and nitrate reductase from nitrogen assimilation (reviewed by Romanowska 2002; Myśliwa-Kurdziel et al. 2002, 2004; Kucera et al. 2008).

There is sufficient experimental evidence to explain the strong impact and inhibitory effect of metals on chloroplast enzymes and proteins which can result in decreased physiological functions and productivity.

Other molecules required for photosynthesis The observed decreased photosynthetic activity and disturbed plastid metabolism may be related to the direct oxidation of NADPH by non-essential metals (e.g., Cd: Böddi et al. 1995; reviewed by Pál et al. 2006; Hg: Lenti et al. 2002; Solymosi et al. 2004, 2006). Excess of non-essential metals 
Fig. 3 Some ultrastructural alterations of chloroplasts under metal excess. a Control chloroplast from Spirodela polyrhiza fronds. b Chloroplast showing symptoms of senescence (containing numerous, large plastoglobuli, fewer stroma thylakoids than the control) from $S$. polyrhiza fronds treated for 8 days with $50 \mu \mathrm{m} \mathrm{Na} \mathrm{NarO}_{4}$. c Developing chloroplast from wheat (Triticum aestivum L.) leaf treated for $12 \mathrm{~h}$ with $600 \mathrm{mM} \mathrm{NaCl} / \mathrm{KCl}$ mixture (1:1 molar ratio). Note the presence of swollen intrathylakoidal space (sometimes appearing as vesicles) and disrupted envelope. d Chloroplast with altered shape (swelling), increased stroma region and bended, bow-like thylakoid arrangement from Phragmites australis leaf treated for 10 days with $15.7 \mu \mathrm{M} \mathrm{CuSO}_{4} x 5 \mathrm{H}_{2} \mathrm{O}$. a, b Courtesy of Áron Keresztes. d Courtesy of Károly Bóka. For more details, see Appenroth et al. (2003) (a, b), Abdelkader et al. (2007); the figure was prepared with Jeol JEM 1011 TEM at $75 \mathrm{kV}$ (c) and Hakmaoui et al. (2007) (d). $E$ envelope (indicated only in case of rupture), $G$ grana, $P g$ plastoglobuli, $S$ starch, $S I$ swollen intrathylakoidal space, St stroma, $T$ thylakoid (stromal thylakoid). The bar indicates $1 \mu \mathrm{m}$

has also been reported to cause high ATP content and also to change gene expression through DNA hypomethylation and DNA damage (reviewed by Poirier et al. 2008). This way, their carcinogenetic effect has also been reported (e.g., Monteiro et al. 2009). Hg-induced inhibition of photosynthesis occurs probably by inducing a severe loss of adenylate pool and decreasing this way the rate of cyclic and non-cyclic photophosphorylation. $\mathrm{Hg}$ also decreases PSII-associated reactions, $\mathrm{O}_{2}$ evolution and $\mathrm{CO}_{2}$ fixation, probably due to the retardation of all ATP-dependent processes (reviewed by Romanowska 2002).

Considering the above-described profound functional, molecular, and metabolic alterations of chloroplasts caused by excess of metals, it is not surprising that the structure of the plastids of metal-stressed plants is also often seriously impacted.

\subsection{Ultrastructural alterations of chloroplasts}

It is rather easy to measure the total metal content in a whole plant or in an organ, but it is rather difficult to quantify metals in organelles such as plastids, as Neuhaus and Wagner (2000), Ramos et al. (2002), or Johnson et al. (2006) did it. Electron microscopy gives information about the integrity of chloroplasts. In the following section, we briefly describe the ultrastructural alterations induced by metal excess at the plastid level.

In the leaves of plants grown in experimental conditions with excess metals, in general, the number of chloroplasts decreases (Table 3; reviewed by Kucera et al. 2008). Structural damages are also frequently observed (Fig. 3). The most common symptoms are the swelling of the organelle, disruption of the envelope, distortion of thylakoids leading to loss of the parallel arrangement of the thylakoid membranes, disorganization of grana, reduction
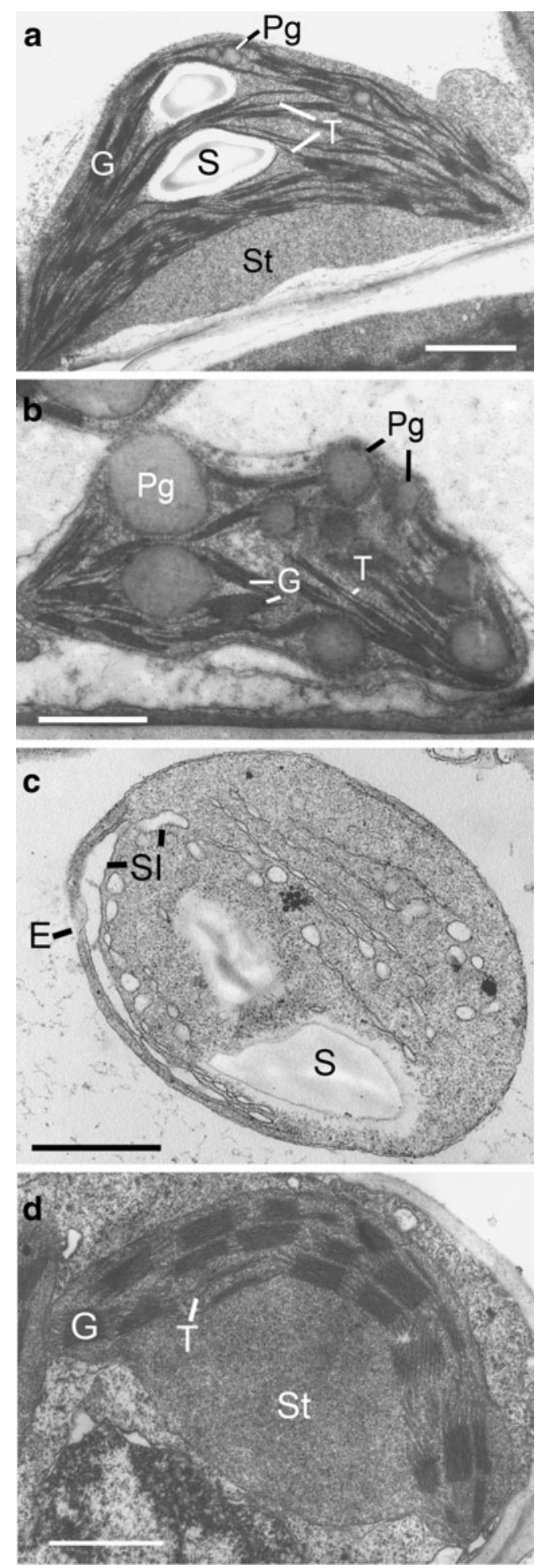

of the thylakoid surface area, and swelling of the intrathylakoidal space (Table 3; reviewed by Barceló and Poschenrieder 2006). There are contradictory data about the changes in the starch content upon metal excess, but often it also increases.

In some cases, different steps of plastid ultrastructural alterations were distinguished as a function of increasing 
concentrations and/or length of metal exposure (e.g., Na: Rahman et al. 2000; Zn: Doncheva et al. 2001). Most studies, however, have been conducted under laboratory conditions (e.g., hydroponic cultures, etc.). In this respect, one of the most natural and most interesting examples is the study of Eleftheriou and Karataglis (1989) in which the ultrastructure of wheat plants grown in "naked spots" of naturally $\mathrm{Cu}$-contaminated soils was studied.

Interestingly, when comparing the alterations of chloroplast ultrastructure in the case of metal deficiency (Table 2) or metal excess (Table 3), we can clearly conclude that with the exception of few specific symptoms, they are very similar. Consequently, unbalanced metal distribution within chloroplasts, more than a specific metal deficiency or excess, is reflected by disorganized thylakoids. This means that typical chloroplasts without any structural alteration could be good indicators of optimal metal distribution within the organelles, although the alterations observed under metal stress resemble those observed under other abiotic or biotic stresses.

\subsection{Alterations on the level of the entire plant}

The sustainability of current land use in agroecosystems can be assessed with respect to metal accumulation in soils by balancing their input and output fluxes. Many studies point to the fact that polluted agricultural lands may produce metal-contaminated crops (e.g., Keller et al. 2002; Muchuweti et al. 2006; reviewed by Witter 1996). The study of Muchuweti et al. (2006) highlights well the potential risks involved in the cultivation and consumption of vegetables on plots irrigated with sewage sludge by pointing out that metal contents in crops may be much higher than the permissible levels established by the Commission Regulation (EU, no. 466/2001). Similarly, crops with higher metal levels than those established by the European Union (EU) and the Food and Agriculture Organization (FAO) of the United Nations (Table 4) are not rarely found when plants are cultivated on contaminated soils or areas with strong atmospheric metal deposition

Table 4 Permissible maximal levels ( $\mathrm{mg} / \mathrm{kg}$ wet weight) of regulated metals established by the joint FAO/WHO Expert Committee on Food Additives (1999) and the Commission Regulation (EU, no. 466/2001) for crops

\begin{tabular}{lll}
\hline Metal & FAO/WHO & EU \\
\hline $\mathrm{Cd}$ & 1 & $0.05-0.2$ \\
$\mathrm{Cu}$ & 40 & 20 \\
$\mathrm{Hg}$ & 1 & - \\
$\mathrm{Pb}$ & 1 & $0.1-0.3$ \\
$\mathrm{Zn}$ & 60 & 50 \\
\hline
\end{tabular}

(e.g., Peris et al. 2007; Sharma et al. 2008a, b; Baize et al. 2009; Mansour et al. 2009a, b; reviewed by Baize 2009).

In general, one third of the micronutrients are translocated to the aboveground organs while two thirds are retained in the roots (e.g., Kawachi et al. 2009; Zhang et al. 2009). When added in excess, most of the surplus metal(s) also accumulates in the roots (e.g., Cd: Jarvis et al. 1976; Obata and Umebayashi 1993; Zhang et al. 2008). Therefore, the accumulation of toxic metals is the most dangerous in the case of root crops (e.g., carrot, radish, sugar beet), but can reach considerable levels also by atmospheric deposition in aboveground organs (for details, see Section 3.3).

Several visible symptoms have been observed in plants grown in metal-polluted areas or in the presence of excess metals. Leaf expansion is inhibited, leaf tissues can become deformed, and chlorosis often occurs (e.g., Cd: Ebbs and Uchil 2008; Ben Ghnaya et al. 2009; Cr: Vázquez et al. 1987; Cu Ciscato et al. 1997; Panou-Filotheou et al. 2001; Mn: González and Lynch 1999; reviewed by Barceló and Poschenrieder 2006; Pb: Woźny et al. 1995; Zn: Ebbs and Uchil 2008; Wang et al. 2009). The decreased growth and biomass of metal-stressed plants can be related to several processes, including disturbances in water and nutritional status or respiration of the plants linked to changes in stomata number, differentiation, and functioning (e.g., Vázquez et al. 1987; Moustakas et al. 1996; Molas 1997).

Taken together, the above results summarized in Section 5 further outline the complicated interrelations and the difficulties in interpreting the effects of metals on the molecular and cellular levels. The careful comparison of the ultrastructural effects induced by essential metal deficiency (Table 2) and excess of metals (Table 3 ) indicates that besides several similar structural alterations, there are, however, few specific differences too. Altogether, plastids and their ultrastructure are relatively sensitive indicators of metal unbalance within plants. Although it has to be mentioned that several other biotic or abiotic stresses may also cause similar ultrastructural alterations, the discussion of these phenomena is beyond the scope of this review.

\section{Conclusions and perspectives}

For plants and also for chloroplasts, the physiological range between deficiency and toxicity of essential metals is narrow (reviewed by Maret and Sandstead 2006). However, more and more reports exist on crop cultivation on soils with unbalanced metal concentrations where, possibly, toxic non-essential elements can also be present.

Plastids possess some mechanisms to cope with metal deficiency or excess, such as the production of specific molecules trapping or chaperoning metals, exporting some 
metals present in excess, and/or sequestrating and storing them in metabolically inactive forms, like for instance the iron-storing ferritin. However, the data reviewed in this work indicate that plastids are highly sensitive to metal stress and their function is often impaired when the metal ion homeostasis of the plant is disturbed. Both essential metal deficiency and excess of metals induce profound molecular, structural, and metabolic alterations that lead to decreased physiological function and, as a consequence, to decreased biomass and productivity. Most vital functions and reactions of chloroplasts require essential metals or are inhibited by metal excess. Therefore, a better understanding of chloroplast metabolism, chloroplast metal uptake, and homeostasis under metal stress is necessary because the optimal functioning of these organelles is essential for high crop productivity. In parallel to laboratory experiments, field assays have to be performed in well-defined conditions (e.g., metal content and $\mathrm{pH}$ in soil, crop species) and with precise prediction/objectives. In such experiments, the data must be considered on the level of the entire organism because plants surely possess several mechanisms to secure physiological ion homeostasis in chloroplasts.

Crops that are cultivated in polluted environments with excess metals have two basically different strategies: avoidance or tolerance, i.e., either they do not absorb potentially toxic elements or they take them up and tolerate them.

In the first case, all transporters at the root periphery and at the endodermis have to be able to prevent the uptake and transport of non-desired elements. Passive apoplastic transport can occur until the endodermis, and at sites of lateral root formation, metals may enter the central cylinder, so the roots are slightly contaminated. Therefore, root crops should preferably not be cultivated in soils with unbalanced metal concentrations. However, occasionally, fortification of border cells occurs and might be responsible for exclusion. Several other exclusion mechanisms exist that involve down-regulation of genes linked to nutrient uptake or protein level modification of channels and transporters that can be observed under excess of essential metals (e.g., $\mathrm{Cu}$ : reviewed by Burkhead et al. 2009; Zn: Kawachi et al. 2009; $\mathrm{K}$ and $\mathrm{Ca}$ and other macronutrients: reviewed by Amtmann and Blatt 2009). On the other hand, there are only few examples for reduced uptake mechanisms for nonessential metals, but these include the synthesis of cysteinerich membrane proteins in the plasma membrane that mediate Cd tolerance by reducing Cd uptake (Song et al. 2004b; Kuramata et al. 2009). Also, concerning $\mathrm{Cd}$, the $\mathrm{ABC}$ transporter AtPDR8 was shown to mediate the extrusion of $\mathrm{Cd}$ out of the plasma membrane of root epidermal cells (Kim et al. 2007). Crop plants with such metal avoidance mechanisms are ideal for a secure crop production.

The interactions between soil, plant roots, and different soil microbes play important roles in regulating metal movement from soil to edible parts of crops and may represent this way an important tool to increase the uptake of required essential elements and/or to decrease the uptake of toxic metals by the plants in soils with unbalanced metal concentrations (e.g., Islam et al. 2007; Ma et al. 2009; reviewed by Burleigh and Bechmann 2002; Hall 2002; Aguilar-Aguilar et al. 2009; Lemanceau et al. 2009; Wenzel 2009). Similarly, the way of irrigation and of course fertilization may also influence metal uptake by plants and their distribution between shoots and roots (Singh and Sinha 2005; Gupta and Sinha 2006; Nair et al. 2008); therefore, it should be considered in sustainable agricultural practice.

When potentially toxic metals enter plants, they get accumulated in variable amounts, preferentially in the roots or in the shoots (Ogundiran and Osibanjo 2008), and plants have to tolerate them somehow. At the cellular level, the toxicity of metals can be reduced, for instance, by retention on the cell wall (e.g., Zhang et al. 2009), sequestration in the vacuole (reviewed by Haydon and Cobbett 2007), or by storage in inactivated forms on specific proteins, amino acids, or peptides. However, if high levels of potentially toxic metals accumulate in edible parts of crops, they constitute a threat to mankind (Sinha et al. 2006). Therefore, knowledge about the molecular events by which metals are taken up by cells or get detoxified could provide potential targets to reduce metal toxicity or to regulate their distribution (e.g., Cailliatte et al. 2009). Detoxification of $\mathrm{Cd}$ can be achieved by members of the heavy metaltransporting P-type ATPase (HMA) subfamily (reviewed by Williams and Mills 2005). For instance, HMA4 is a $\mathrm{Zn} / \mathrm{Cd}$ transporter that confers plant tolerance to $\mathrm{Cd}$ by loading it into the xylem, thus increasing translocation to the shoot where it might have less damaging effects for the plants (Verret et al. 2004; Hanikenne et al. 2008). The translocation of metals in plants can also be controlled by producing transgenic plants. For instance, Hanikenne et al. (2008) constructed a transgenic plant of Arabidopsis thaliana with altered metal partitioning between roots and shoots. Future research should address the possibility of modifying the tissue- or organ-specific expression and/or ion selectivity of metal transporters, for example, to enhance the sequestration of non-essential elements in root vacuoles if the edible part of the plant is on the shoot (reviewed by Palmgren et al. 2008). An alternative to reduce toxicity in plants might be to express non-essential element export systems at the root level.

When metal-unbalanced lands may be used for crop production, genetically modified crops could be cultivated on them. The genetic modification in such organisms should be chosen in such a way that edible parts contain balanced metal concentrations. It means that the edible parts should be devoid of toxic elements and should contain 
enough essential nutrients. To fight against malnutrition due to essential element deficiency in edible parts of crops, biofortification has been suggested (reviewed by Nestel et al. 2006; Yang et al. 2007; Palmgren et al. 2008; White and Broadley 2009). The aim is to produce crops enriched in $\mathrm{Fe}, \mathrm{Zn}, \mathrm{Cu}, \mathrm{Ca}, \mathrm{Mg}, \mathrm{Se}$, and $\mathrm{I}$, but also in "promoter" substances, such as ascorbate (vitamin C), beta-carotene, cysteine-rich polypeptides, and certain organic and amino acids, which stimulate the absorption of essential mineral elements by the gut (reviewed by White and Broadley 2009). The seeds of legumes generally have far higher concentrations of $\mathrm{Fe}$ and $\mathrm{Zn}$ than seeds of cereals (reviewed by White and Broadley 2009). This highlights the importance of the choice of plant species in strategies designed to increase the delivery of mineral elements to vulnerable populations. Another knowledge to consider is the fact that some elements such as $\mathrm{Se}$ and $\mathrm{Mg}$ are transported readily in the phloem while others such as $\mathrm{Fe}, \mathrm{Zn}, \mathrm{Cu}$, and I are not, and $\mathrm{Ca}$ has little phloem mobility (reviewed by White and Broadley 2009). Thus, phloem-fed tissues such as fruits, seeds, and tubers are often poor sources of $\mathrm{Fe}, \mathrm{Zn}, \mathrm{Cu}$, I, and $\mathrm{Ca}$, while leafy vegetables are rich sources of these elements. Zn- or Fe-enriched cereal grains would potentially generate major health benefits. Moreover, adequate $\mathrm{Zn}$ content is known to enhance crop productivity (reviewed by Cakmak 2008). Finally, it is worth mentioning that once in place, the biofortified crop system is highly sustainable (reviewed by Nestel et al. 2006).

Acknowledgments The European Union and the European Social Fund have provided financial support to K. S. (grant agreement no. TÁMOP 4.2.1./B-09/1/KMR-2010-0003). The authors are grateful to Judit Bohák for help with the preparation of the manuscript.

\section{References}

Abdel-Ghany SE (2009) Contribution of plastocyanin isoforms to photosynthesis and copper homeostasis in Arabidopsis thaliana grown at different copper regimes. Planta 229:767-779. doi:10.1007/s00425-008-0869-z

Abdel-Ghany SE, Müller-Moulé P, Niyogi KK, Pilon M, Shikanai T (2005) Two P-type ATPases are required for copper delivery in Arabidopsis thaliana chloroplasts. Plant Cell 17:1233-1251. doi:10.1105/tpc.104.030452

Abdelkader AF, Aronsson H, Solymosi K, Böddi B, Sundqvist C (2007) High salt stress induces swollen prothylakoids in darkgrown wheat and alters both prolamellar body transformation and reformation after irradiation. J Exp Bot 58:2553-2564. doi: $10.1093 / \mathrm{jxb} / \mathrm{erm} 085$

Adams ML, Norvell WA, Philpot WD, Peverly JH (2000) Micronutrient status. Spectral detection of micronutrient deficiency in 'Bragg' soybean. Agron J 92:261-268

Aguilar-Aguilar S, Perez-Moreno J, Ferrera-Cerrato R, Grimaldo-Juárez O, Cervantes-Díazi L, González-Mendoza D (2009) Ectomycorrhizal fungi and tolerance to salinity in plants. Rev Chil Hist Nat 82:163168. doi:10.4067/S0716-078X2009000100011 (in Spanish)
Allen RD (1995) Dissection of oxidative stress tolerance using transgenic plants. Plant Physiol 107:1049-1057

Alloway BJ (1995) Heavy metals in soils, 2nd edn. Blackie Academic, London

Amtmann A, Blatt MR (2009) Regulation of macronutrient transport. New Phytol 181:35-52. doi:10.1111/j.1469-8137.2008.02666.x

Antonious GF, Snyder JC (2007) Accumulation of heavy metals in plants and potential phytoremediation of lead by potato, Solanum tuberosum. L. J Environ Sci Health Part A Toxic/Hazard Subst Environ Eng 42:811-816. doi:10.1080/10934520701304757

Appenroth K-J, Keresztes Á, Sárvári É, Jaglarz A, Fischer W (2003) Multiple effects of chromate on Spirodela polyrhiza: electron microscopy and biochemical investigations. Plant Biol 5:315323. doi:10.1055/s-2003-40801

Aravind P, Prasad MNV (2004) Zinc protects chloroplasts and associated photochemical functions in cadmium exposed Ceratophyllum demersum L.: a freshwater macrophyte. Plant Sci 166:1321-1327. doi:10.1016/j.plantsci.2004.01.011

Arora M, Kiran B, Rani S, Rani A, Kaur B, Mittal N (2008) Heavy metal accumulation in vegetables irrigated with water from different sources. Food Chem 111:811-815. doi:10.1016/j.foodchem. 2008.04.049

Arosio P, Levi S (2002) Ferritin, iron homeostasis, and oxidative damage. Free Radic Biol Med 15:457-463

Babu TS, Marder JB, Tripuranthakam S, Dixon DG, Greenberg BM (2001) Synergistic effects of a photooxidized polycyclic aromatic hydrocarbon and copper on photosynthesis and plant growth: evidence that in vivo formation of reactive oxygen species is a mechanism of copper toxicity. Environ Toxicol Chem 20:13511358. doi:10.1002/etc. 5620200626

Bailey S, Silva P, Nixon P, Mullineaux C, Robinson C, Mann N (2001) Auxiliary functions in photosynthesis: the role of the FtsH protease. Biochem Soc Trans 29:455-459

Baize D (2009) Cadmium in soils and cereal grains after sewagesludge application on French soils: a review. Agron Sustain Dev 29:175-184. doi:10.1051/agro:2008031

Baize D, Bellanger L, Tomassone R (2009) Relationships between concentrations of trace metals in wheat grains and soil. Agron Sustain Dev 29:297-312. doi:10.1051/agro:2008057

Baranova EN, Gulevich AA, Polyakov VYU (2007) Effect of $\mathrm{NaCl}$, $\mathrm{Na}_{2} \mathrm{SO}_{4}$ and mannitol on utilization of storage starch and formation of plastids in the cotyledons and roots of alfalfa seedlings. Russian J Plant Physiol 54:50-57. doi:10.1134/ S1021443707010086

Barceló J, Poschenrieder C (2006) Structural and ultrastructural changes in heavy metal exposed plants. In: Prasad MNV (ed) Heavy metal stress in plants: from biomolecules to ecosystems, 2nd edn. Springer, Berlin, pp 223-248

Barceló J, Vázquez MD, Poschenrieder C (1988) Structural and ultrastructural disorders in cadmium-treated bush bean plants (Phaseolus vulgaris L.). New Phytol 108:37-49

Barón M, Arellano JB, Gorgé JL (1995) Copper and photosystem II: a controversial relationship. Physiol Plant 94:174-180. doi:10.1111/j.1399-3054.1995.tb00799.x

Baryla A, Carrier P, Franck F, Coulomb C, Sahut C, Havaux M (2001) Leaf chlorosis in oilseed rape (Brassica napus) grown on cadmium polluted soil: causes and consequences for photosynthesis and growth. Planta 212:696-709. doi:10.1007/s004250000439

Basar H (2009) Methods for estimating phytoavailable metals in soils. Comm Soil Sci Plant Anal 40:1057-1105. doi:10.1080/ 00103620902753764

Baszyński T, Ruszkowska M, Król M, Tukendorf A, Wolinska D (1978) The effect of copper deficiency on the photosynthetic apparatus of higher plants. Z Pflanzenphysiol 89:207-216

Baszyński T, Wajda L, Król M, Wolińska D, Krupa Z, Tukendorf A (1980) Photosynthetic activities of cadmium treated tomato 
plants. Physiol Plant 48:365-370. doi:10.1111/j.1399-3054.1980. tb03269.x

Baszyński T, Tukendorf A, Ruszkowska M, Skorzyńska E, Maksymiec W (1988) Characteristics of the photosynthetic apparatus of coppertolerant spinach expose to excess copper. J Plant Physiol 132:708-713

Beale SI (1999) Enzymes of chlorophyll biosynthesis. Photosynth Res 60:43-73. doi:10.1023/A:1006297731456

Ben Ammar W, Nouairi I, Zarrouk M, Jemal F (2007) Cadmium stress induces changes in the lipid composition and biosynthesis in tomato (Lycopersicon esculentum Mill.) leaves. Plant Growth Regul 53:75-85. doi:10.1007/s10725-007-9203-1

Ben Ghnaya A, Charles G, Hourmant A, Ben HJ, Branchard M (2009) Physiological behaviour of four rapeseed cultivar (Brassica napus L.) submitted to metal stress. CR Biologies 332:363370. doi:10.1007/s10725-007-9203-1

Bernal M, Sánchez-Testillano P, Risueño MC, Yruela I (2006) Excess copper induces structural changes in cultured photosynthetic soybean cells. Funct Plant Biol 33:1001-1012. doi:10.1071/ FP06174

Bertrand M, Poirier I (2005) Photosynthetic organisms and excess of metals. Photosynthetica 43:345-353. doi:10.1007/s11099-0050058-2

Bertrand M, Schoefs B, Siffel P, Rohacek K, Molnar I (2001) Cadmium inhibits epoxidation of diatoxanthin to diadinoxanthin in the xanthophyll cycle of the marine diatom Phaeodactylum tricornutum. FEBS Lett 508:153-156

Bi X, Feng X, Yang Y, Qiu G, Li G, Li F, Liu T, Fu Z, Jin Z (2006) Environmental contamination of heavy metals from zinc smelting areas in Hezhang County, western Guizhou, China. Environ Int 32:883-890. doi:10.1016/j.envint.2006.05.010

Böddi B, Oravecz AR, Lehoczki E (1995) Effect of cadmium on organization and photoreduction of protochlorophyllide in darkgrown leaves and etioplast inner membrane preparations of wheat. Photosynthetica 31:411-420

Boening DW (2000) Ecological effects, transport and fate of mercury: a general review. Chemosphere 40:1335-1351. doi:10.1016/ S0045-6535(99)00283-0

Briat J-F, Vert G (2004) Acquisition et gestion du fer par les plantes. Cahiers Agricult 13:183-201 (in French)

Briat J-F, Lobréaux S, Grignon N, Vansuyt G (1999) Regulation of plant ferritin synthesis: how and why. Cell Mol Life Sci 56:155166. doi: $10.1007 / \mathrm{s} 000180050014$

Briat J-F, Curie C, Gaymard F (2007) Iron utilization and metabolism in plants. Curr Opin Plant Biol 10:276-282. doi:10.1016/j. pbi.2007.04.003

Broadley MR, White PJ, Hammond JP, Zelko I, Lux A (2007) Zinc in plants. New Phytol 173:677-702. doi:10.1111/j.14698137.2007.01996.x

Burkhead JL, Gogolin Reynolds KA, Abdel-Ghany SE, Cohu CM, Pilon M (2009) Copper homeostasis. New Phytol 182:799-816. doi:10.1111/j.1469-8137.2009.02846.x

Burleigh SH, Bechmann IE (2002) Plant nutrient transporter regulation in arbuscular mycorrhizas. Plant Soil 244:247-251. doi:10.1023/A:1020227232140

Bushnell TP, Bushnell D, Jagendorf AT (1993) A purified zinc protease of pea chloroplasts, EPI, degrades the large subunit of ribulose-1,5-bisphosphate carboxylase/oxygenase. Plant Physiol 103:585-591

Cailliatte R, Lapeyre B, Briat J-F, Mari S, Curie C (2009) The NRAMP6 metal transporter contributes to cadmium toxicity. Biochem J 422:217-228. doi:10.1042/BJ20090655

Cakmak I (2000) Possible roles of zinc in protecting plant cells from damage by reactive oxygen species. New Phytol 146:185-205

Cakmak I (2008) Enrichment of cereal grains with zinc: agronomic or genetic biofortification? Plant Soil 302:1-17. doi:10.1007/ s11104-007-9466-3
Carrier P, Baryla A, Havaux M (2003) Cadmium distribution and microlocalization in oilseed rape (Brassica napus) after longterm growth on cadmium-contaminated soil. Planta 216:939950. doi:10.1007/s00425-002-0947-6

Chen W, Yang X, He Z, Feng Y, Hu F (2008) Differential changes in photosynthetic capacity, $77 \mathrm{~K}$ chlorophyll fluorescence and chloroplast ultrastructure between Zn-efficient and Zn-inefficient rice genotypes (Oryza sativa) under low zinc stress. Physiol Plant 132:89-101. doi:10.1111/j.1399-3054.2007.00992.x

Chen C, Huang D, Liu J (2009) Functions and toxicity of nickel in plants: recent advances and future prospects. Clean Soil Air Water 37:304-313. doi:10.1002/clen.200800199

Cho UH, Park JO (2000) Mercury-induced oxidative stress in tomato seedlings. Plant Sci 156:1-9. doi:10.1016/S0168-9452(00)00227-2

Ciscato M, Valcke R, van Loven K, Clijsters H, Navari-Izzo F (1997) Effects of in vivo copper treatment on the photosynthetic apparatus of two Triticum durum cultivars with different stress sensitivity. Physiol Plant 100:901-908. doi:10.1111/j.13993054.1997.tb00016.x

Clemens S, Naumann B, Hippler M (2009) Proteomics of metal mediated protein dynamics in plants-iron and cadmium in the focus. Front Biosci 14:1955-1969

Cobbett CS (2000) Phytochelatins and their roles in heavy metal detoxification. Plant Physiol 123:825-832

Codex Committee on Food Additives and Contaminants (1995) Revised discussion paper on $\mathrm{Pb}$. CS/FAC. 95/18 add.2

Commission Regulation (EC) no. 466/2001

Cornah JE, Roper JM, Singh DP, Smith AG (2002) Measurement of ferrochelatase activity using a novel assay suggests that plastids are the major site of haem biosynthesis in both photosynthetic and non-photosynthetic cells of pea (Pisum sativum L.). Biochem J 362:423-432

Curie C, Alonso JM, Le Jean M, Ecker JR, Briat J-F (2000) Involvement of NRAMP1 from Arabidopsis thaliana in iron transport. Biochem J 347:749-755

Devi SR, Prasad MNV (2006) Membrane lipid alterations in heavy metal exposed plants. In: Prasad MNV (ed) Heavy metal stress in plants: from biomolecules to ecosystems, 2nd edn. Springer, Berlin, pp 127-145

Djebali W, Zarrouk M, Brouquisse R, El KS, Limam F, Ghorbel MH, Chaïbi W (2005) Ultrastructure and lipid alterations induced by cadmium in tomato (Lycopersicon esculentum) chloroplast membranes. Plant Biol 7:358-368. doi:10.1055/s-2005-837696

Doncheva S, Stoyanova Z, Velikova V (2001) Influence of succinate on zinc toxicity of pea plants. J Plant Nutr 24:789-804. doi:10.1081/PLN-100103774

Drazkiewicz M, Baszyński T (2005) Growth parameters and photosynthetic pigments in leaf segments of Zea mays exposed to cadmium, as related to protection mechanisms. J Plant Physiol 162:1013-1021. doi:10.1016/j.jplph.2004.10.010

Drazkiewicz M, Skórzyńska-Polit E, Krupa Z (2004) Copper-induced oxidative stress and antioxidant defence in Arabidopsis thaliana. Biometals 17:379-387. doi:10.1023/B:BIOM.0000029417.18154.22

Droppa M, Terry N, Horváth G (1984) Effects of $\mathrm{Cu}$ deficiency on photosynthetic electron transport. Proc Natl Acad Sci USA 81:2369-2373

Drummond RSM, Tutone A, Li Y-C, Gardner RC (2006) A putative magnesium transporter AtMRS2-11 is localized to the plant chloroplast envelope membrane system. Plant Sci 170:78-89. doi:10.1016/j.plantsci.2005.08.018

Dudka S, Miller WP (1999) Accumulation of potentially toxic elements in plants and their transfer to human food chain. $\mathrm{J}$ Environ Sci Health, Part B 34:681-708. doi:10.1080/ 03601239909373221

Duy D, Wanner G, Meda AR, von Wiren N, Soll J, Philippar K (2007) PIC1, an ancient permease in Arabidopsis chloroplasts, mediates iron transport. Plant Cell 19:986-1006 
Ebbs S, Uchil S (2008) Cadmium and zinc induced chlorosis in Indian mustard (Brassica juncea (L.) Czern) involves preferential loss of chlorophyll $b$. Photosynthetica 46:49-55. doi:10.1007/s11099008-0010-3

Eleftheriou EP, Karataglis S (1989) Ultrastructural and morphological characteristics of cultivated wheat growing on copper-polluted fields. Bot Acta 102:134-140

El-Naim MA, El-Housseini M, Naeem MH (2004) Safety use of sewage sludge as soil conditioner. J Environ Sci Health Part A Toxic/Hazard Subst Environ Eng 39:435-444. doi:10.1081/ESE120027534

Ettinger WF, Clear AM, Fanning KJ, Peck ML (1999) Identification of a $\mathrm{Ca}^{2+} / \mathrm{H}^{+}$antiport in the plant chloroplast thylakoid membrane. Plant Physiol 119:1379-1385

Faller P, Kienzler K, Krieger-Liszkay A (2005) Mechanism of $\mathrm{Cd}^{2+}$ toxicity: $\mathrm{Cd}^{2+}$ inhibits photoactivation of Photosystem II by competitive binding to the essential $\mathrm{Ca}^{2+}$ site. Biochim Biophys Acta 1706:158-164. doi:10.1016/j.bbabio.2004.10.005

Fodor F (2006) Heavy metals competing with iron under conditions involving phytoremediation. In: Barton LL, Abadía J (eds) Iron nutrition in plants and rhizospheric microorganisms. Springer, Heidelberg, pp 129-151

Gabbrielli R, Pandolfini T, Espen L, Palandri MR (1999) Growth, peroxidase activity and cytological modifications in Pisum sativum seedlings exposed to $\mathrm{Ni}^{2+}$ toxicity. J Plant Physiol 155:639-645

Gallego SM, Benavides MP, Tomaro ML (1996) Effect of heavy metal ion excess on sunflower leaves: evidence for involvement of oxidative stress. Plant Sci 121:151-159. doi:10.1016/S01689452(96)04528-1

Giannakoula A, Moustakas M, Mylona P, Papadakis I, Yupsani T (2008) Aluminum tolerance in maize is correlated with increased levels of mineral nutrients, carbohydrates and proline, and decreased levels of lipid peroxidation and $\mathrm{Al}$ accumulation. J Plant Physiol 165:385-396. doi:10.1016/j. jplph.2007.01.014

González A, Lynch JP (1999) Subcellular and tissue Mn compartmentation in bean leaves under Mn toxicity stress. Austr J Plant Physiol 26:811-822

Grace SC (1990) Phylogenetic distribution of superoxide dismutase supports an endosymbiotic origin for chloroplasts and mitochondria. Life Sci 47:1875-1886. doi:10.1016/0024-3205(90)90399-C

Grotz N, Guerinot ML (2006) Molecular aspects of $\mathrm{Cu}, \mathrm{Fe}$ and $\mathrm{Zn}$ homeostasis in plants. Biochim Biophys Acta 1763:595-608. doi:10.1016/j.bbamcr.2006.05.014

Grotz N, Fox T, Connolly E, Park W, Guerinot ML, Eide D (1998) Identification of a family of zinc transporter genes from Arabidopsis that respond to zinc deficiency. Proc Natl Acad Sci USA 95:7220-7224

Grusak MA, Pearson JN, Marentes E (1999) The physiology of micronutrient homeostasis in field crops. Field Crops Res 60:4156. doi:10.1016/S0378-4290(98)00132-4

Guerinot ML (2000) The ZIP family of metal transporters. Biochim Biophys Acta 1465:190-198. doi:10.1016/S0005-2736(00) 00138-3

Guo T, Chen Y, Zhang Y-H, Jin Y-F (2006) Alleviation of Al toxicity in barley by addition of calcium. Agric Sci China 5:828-833. doi:10.1016/S1671-2927(06)60131-4

Gupta AK, Sinha S (2006) Chemical fractionation and heavy metal accumulation in the plant of Sesamum indicum (L.) var. T55 grown on soil amended with tannery sludge: selection of single extractants. Chemosphere 64:161-173. doi:10.1016/j.chemo sphere.2005.10.016

Hagemeyer J (2006) Ecophysiology of plant growth under heavy metal stress. In: Prasad MNV (ed) Heavy metal stress in plants: from biomolecules to ecosystems, 2nd edn. Springer, Berlin, pp 201-222
Hakmaoui A, Ater M, Bóka K, Barón M (2007) Copper and cadmium tolerance, uptake and effect on chloroplast ultrastructure. Studies on Salix purpurea and Phragmites australis. Z Naturforsch 62c:417-126

Hall JL (2002) Cellular mechanisms for heavy metal detoxification and tolerance. J Exp Bot 53:1-11

Hall JL, Williams LE (2003) Transition metal transporters in plants. J Exp Bot 54:2601-2613

Hall JD, Barr R, Al-Abbas AH, Crane FL (1972) The ultrastructure of chloroplasts in mineral-deficient maize leaves. Plant Physiol 50:404-409

Hanikenne M, Talke IN, Haydon MJ, Lanz C, Nolte A, Motte P, Kroymann J, Weigel D, Krämer U (2008) Evolution of metal hyperaccumulation required cis-regulatory changes and copy number expansion of HMA4. Nature 453:391-395. doi:10.1038/nature06877

Hänsch R, Mendel RR (2009) Physiological functions of mineral micronutrients $(\mathrm{Cu}, \mathrm{Zn}, \mathrm{Mn}, \mathrm{Fe}, \mathrm{Ni}, \mathrm{Mo}, \mathrm{B}, \mathrm{Cl})$. Curr Opin Plant Biol 12:259-266. doi:10.1016/j.pbi.2009.05.006

Hasan R, Ohnuki Y, Kawasaki M, Taniguchi M, Miyake H (2005) Differential sensitivity of chloroplasts in mesophyll and bundle sheath cells in maize, an NADP-malic enzyme-type $\mathrm{C}_{4}$ plant, to salinity stress. Plant Prod Sci 8:567-577

Haydon MJ, Cobbett CS (2007) Transporters of ligands for essential metal ions in plants. New Phytol 174:499-506. doi:10.1111/ j.1469-8137.2007.02051.x

Henriques FS (2001) Loss of blade photosynthetic area and of chloroplasts' photochemical capacity account for reduced $\mathrm{CO}_{2}$ assimilation rates in zinc-deficient sugar beet leaves. J Plant Physiol 158:915-919. doi:10.1078/0176-1617-00274

Henriques FS (2003) Gas exchange, chlorophyll $a$ fluorescence kinetics and lipid peroxidation of pecan leaves with varying manganese concentrations. Plant Sci 165:239-244. doi:10.1016/ S0168-9452(03)00163-8

Henriques FS (2004) Reduction in chloroplast number accounts for the decrease in the photosynthetic capacity of Mn-deficient pecan leaves. Plant Sci 166:1051-1055. doi:10.1016/j.plantsci.2003.12.022

Hernandez JA, Olmos E, Corpas FJ, Sevilla F, del Rio LA (1995) Saltinduced oxidative stress in chloroplasts of pea plants. Plant Sci 105:151-167. doi:10.1016/0168-9452(94)04047-8

Hill KA, Lion LW, Ahner BA (2002) Reduced Cd accumulation in Zea mays: a protective role for phytosiderophores? Environ Sci Technol 15:5363-5368

Huang L, Berkelman T, Franklin AE, Hoffman NE (1993) Characterization of a gene encoding a $\mathrm{Ca}^{2+}$-ATPase-like protein in the plastid envelope. Proc Natl Acad Sci USA 90:10066-10070

Islam E, Yang X, He Z, Mahmood Q (2007) Assessing potential dietary toxicity of heavy metals in selected vegetables and food crops. $\mathrm{J}$ Zhejiang Univ Sci B 8:1-13. doi:10.1631/jzus.2007.B0001

Izaguirre-Mayoral ML, Sinclair TR (2005) Soybean genotypic difference in growth, nutrient accumulation and ultrastructure in response to manganese and iron supply in solution culture. Ann Bot 96:149-158. doi:10.1093/aob/mci160

Izaguirre-Mayoral ML, Sinclair TR (2009) Irradiance regulates genotype-specific responses of Rhizobium-nodulated soybean to increasing iron and two manganese concentrations in solution culture. J Plant Physiol 166:807-818. doi:10.1016/j. jplph.2008.10.006

Jamali MK, Kazia TG, Araina MB, Afridi HI, Jalbani N, Kandhroa GA, Shaha AQ, Baiga JA (2009) Heavy metal accumulation in different varieties of wheat (Triticum aestivum L.) grown in soil amended with domestic sewage sludge. J Hazard Mater 164:1386-1391. doi:10.1016/j.jhazmat.2008.09.056

Jarvis SC, Jones LHP, Hopper MJ (1976) Cadmium uptake from solution by plants and its transport from roots to shoots. Plant Soil 44:179-191. doi:10.1007/BF00016965 
Jemal F, Zarrouk M, Ghorbal MH (2000) Effect of cadmium on lipid composition of pepper. Biochem Soc Trans 28:907-910

Ji ZH, Korcak RF, Wergin WP, Fan F, Faust M (1984) Cellular ultrastructure and net photosynthesis of apple seedlings under iron stress. J Plant Nutr 7:911-928. doi:10.1080/01904168409363254

Johnson CH, Shingles J, Ettinger WF (2006) Regulation and role of calcium fluxes in the chloroplast. In: Wise RR, Hoober KJ (eds) Advances in photosynthesis and respiration, vol 23, The structure and function of plastids. Dordrecht, The Netherlands, pp 403416

Joint FAO/WHO Expert Committee on Food Additives (1999) Summary and conclusions. 53 rd Meeting, Rome, June 1-10

Kawachi M, Kobae Y, Mori H, Tomioka R, Lee Y, Maeshima M (2009) A mutant strain Arabidopsis thaliana that lacks vacuolar membrane zinc transporter MTP1 revealed the latent tolerance to excessive zinc. Plant Cell Physiol 50:1156-1170. doi:10.1093/ $\mathrm{pcp} / \mathrm{pcp} 067$

Keller A, Abbaspour KC, Schulin R (2002) Assessment of uncertainty and risk in modeling regional heavy-metal accumulation in agricultural soils. J Environ Qual 31:175-187

Khan HR, McDonald GK, Rengel Z (2004) Zinc fertilization and water stress affects plant water relations, stomatal conductance and osmotic adjustment in chickpea (Cicer arientinum L.). Plant Soil 267:271-284. doi:10.1016/j.pbi.2009.04.003

Khavari-Nejad RA, Mostofi Y (1998) Effects of $\mathrm{NaCl}$ on photosynthetic pigments, saccharides, and chloroplast ultrastructure in leaves of tomato cultivars. Photosynthetica 35:151-154. doi:10.1023/A:1006846504261

Kidd P, Barcelo J, Bernal MP, Navari-Izzo F, Poschenrieder C, Shilev S, Clemente R, Monterroso C (2009) Trace element behaviour at the root-soil interface: implications in phytoremediation. Environ Exp Botany 67:243-259. doi:10.1016/j.envexpbot.2009.06.013

Kim DY, Bovet L, Maeshima M, Martinoia E, Lee Y (2007) The ABC transporter AtPDR8 is a cadmium extrusion pump conferring heavy metal resistance. Plant J 50:207-218. doi:10.1111/j.1365313X.2007.03044.X

Kim Y-Y, Choi H, Segami S, Cho H-T, Martinoia E, Maeshima M, Lee Y (2009) AtHMA1 contributes to the detoxification of excess Zn(II) in Arabidopsis. Plant J 58:737-753. doi:10.1111/ j.1365-313X.2009.03818.x

Kochian LV (1995) Cellular mechanisms of aluminum toxicity and resistance in plants. Annu Rev Plant Physiol Plant Mol Biol 46:237-260

Kochian LV, Hoekenga OA, Pineros MA (2004) How do crop plants tolerate acid soils? Mechanisms of aluminum tolerance and phosphorous efficiency. Annu Rev Plant Biol 55:459-493

Kucera T, Horáková H, Sonská A (2008) Toxic metal ions in photoautotrophic organisms. Photosynthetica 46:481-489. doi:10.1007/s11099-008-0083-Z

Küpper H, Küpper F, Spiller M (1996) Environmental relevance of heavy metal-substituted chlorophylls using the example of water plants. J Exp Bot 47:259-266

Küpper H, Küpper F, Spiller M (1998) In situ detection of heavy metal substituted chlorophylls in water plants. Photosynth Res 58:123133. doi:10.1023/A:1006132608181

Küpper H, Šetlik I, Spiller M, Küpper FC, Prášil O (2002) Heavy metal-induced inhibition of photosynthesis: targets of in vivo heavy metal chlorophyll formation. J Phycol 38:429-441. doi:10.1046/j.1529-8817.2002.01148.x

Küpper H, Setlík I, Setliková E, Ferimazova N, Spiller M, Küpper FC (2003) Copper-induced inhibition of photosynthesis: limiting steps of in vivo copper chlorophyll formation in Scenedesmus quadricauda. Funct Plant Biol 30:1187-1196. doi:10.1071/ FP03129

Kuramata M, Masuya S, Takahashi Y, Kitagawa E, Inoue C, Ishikawa S, Youssefian S, Kusano T (2009) Novel cysteine-rich peptides from Digitaria ciliaris and Oryza sativa enhance tolerance to cadmium by limiting its cellular accumulation. Plant Cell Physiol 50:106-117. doi:10.1093/pcp/pen 175

Leigh RA, Tomos AD (1993) Ion distribution in cereal leaves: pathways and mechanisms. Philos Trans R Soc Lond Series B: Biol Sci 341:75-86

Lemanceau P, Bauer P, Kraemer S, Briat J-F (2009) Iron dynamics in the rhizosphere as a case study for analyzing interactions between soils, plants and microbes. Plant Soil 321:513-535. doi:10.1007/ s11104-009-0039-5

Lenti K, Fodor F, Böddi B (2002) Mercury inhibits the activity of the NADPH:protochlorophyllide oxidoreductase (POR). Photosynthetica 40:145-151. doi:10.1023/A:1020143602973

Lidon FC, Henriques FS (1991) Limiting step in photosynthesis of rice plants treated with varying copper levels. J Plant Physiol 138:115-118

Lidon FC, Henriques FS (1993) Changes in the thylakoid membrane polypeptide patterns triggered by excess $\mathrm{Cu}$ in rice. Photosynthetica 28:109-117

Lidon FC, Teixeira MG (2000a) Oxy radicals production and control in the chloroplast of Mn-treated rice. Plant Sci 152:7-15. doi:10.1016/S0168-9452(99)00179-X

Lidon FC, Teixeira MG (2000b) Rice tolerance to excess Mn: implications in the chloroplast lamellae and synthesis of a novel Mn protein. Plant Physiol Biochem 38:969-978. doi:10.1016/ S0981-9428(00)01207-9

Lidon FC, Ramalho JC, Henriques FS (1993) Copper inhibition of rice photosynthesis. J Plant Physiol 142:12-17

Lidon FC, Barreiro MG, Ramalho JC (2004) Manganese accumulation in rice: implications for photosynthetic functioning. J Plant Physiol 161:1235-1244. doi:10.1016/j.jplph.2004.02.003

Ma Y, Rajkumar M, Freitas H (2009) Inoculation of plant growth promoting bacterium Achromobacter xylosoxidans strain Ax10 for the improvement of copper phytoextraction by Brassica juncea. J Environ Manage 90:831-837. doi:10.1016/j.jenv man.2008.01.014

Maathuis FJM (2009) Physiological functions of mineral macronutrients. Curr Opin Plant Biol 12:250-258. doi:10.1016/j. pbi.2009.04.003

Mahmoudi H, Labidi N, Ksouri R, Gharsalli M, Abdelly C (2007) Differential tolerance to iron deficiency of chickpea varieties and Fe resupply effects. CR Biologies 330:237-246. doi:10.1016/j. crvi.2007.02.007

Maksymiec W (1997) Effect of copper on cellular processes in higher plants. Photosynthetica 34:321-342. doi:10.1023/A:1006818815528

Maksymiec W, Russa R, Urbanik-Sypniewska T, Baszyński T (1992) Changes in acyl lipid and fatty acid composition in thylakoids of copper non-tolerant spinach exposed to excess copper. J Plant Physiol 140:52-55

Maksymiec W, Russa R, Urbanik-Stypiewska T, Baszyński T (1994) Effect of excess $\mathrm{Cu}$ on the photosynthetic apparatus of runner bean leaves treated at two different growth stages. Physiol Plant 91:715-721. doi:10.1111/j.1399-3054.1994.tb03010.x

Maksymiec W, Bednara J, Baszyński T (1995) Responses of runner bean plants to excess copper as a function of plant growth stages: effects on morphology and structure of primary leaves and their chloroplast ultrastructure. Photosynthetica 31:427-435

Mansour SA, Belal MH, Abou-Arab AAK, Ashour HM, Gad MF (2009a) Evaluation of some pollutant levels in conventionally and organically farmed potato tubers and their risks to human health. Food Chem Toxicol 47:615-624. doi:10.1016/j. fct.2008.12.019

Mansour SA, Belal MH, Abou-Arab AAK, Gad MF (2009b) Monitoring of pesticides and heavy metals in cucumber fruits produced from different farming systems. Chemosphere 75:601609. doi:10.1016/j.chemosphere.2009.01.058 
Manthey JA, Crowley DE, Luster DG, Douglas G (1994) Biochemistry of metal micronutrients in the rhizosphere. Lewis, Boca Raton

Mapanda F, Mangwayana EN, Nyamangara J, Giller KE (2005) The effect of long-term irrigation using wastewater on heavy metal contents of soils under vegetables in Harare, Zimbabwe. Agric Ecosyst Environ 107:151-165. doi:10.1016/j.chemo sphere.2009.01.058

Maret W, Sandstead HH (2006) Zinc requirements and the risks and benefits of zinc supplementation. J Trace Elem Med Biol 20:3 18. doi:10.1016/j.jtemb.2006.01.006

Marschner H (1995) Mineral nutrition of higher plants. Academic, London

McCarthy I, Romero-Puertas MC, Palma JM, Sandalio LM, Corpas FJ, Gómez M, del Rio LA (2001) Cadmium induces senescence symptoms in leaf peroxisomes of pea plants. Plant Cell Environ 24:1065-1073. doi:10.1046/j.1365-3040.2001.00750.x

McQuattie CH, Schier GA (2000) Response of sugar maple (Acer saccharum) seedlings to manganese. Can J Forest Res 30:456467. doi:10.1139/cjfr-30-3-456

Mercer FV, Nittim M, Possingham JV (1962) The effect of manganese deficiency on the structure of spinach chloroplasts. J Cell Biol 15:379-381

Mico C, Recatalá L, Peris M, Sánchez J (2006) Assessing heavy metal sources in agricultural soils of an European Mediterranean area by multivariate analysis. Chemosphere 65:863-872

Misra A, Dwivedi S, Srivastava AK, Tewari DK, Khan A, Kumar R (2006) Low iron stress nutrition for evaluation of Fe-efficient genotype physiology, photosynthesis, and essential monoterpene oil(s) yield of Ocimum sanctum. Photosynthetica 44:474-477. doi:10.1007/s11099-006-0054-1

Mitsuya S, Takeoka Y, Miyake H (2000) Light dependency of salinityinduced chloroplast damages. J Plant Physiol 157:661-667

Mitsuya S, Kawasaki M, Taniguchi M, Miyake H (2003) Light dependency of salinity-induced chloroplast degradation. Plant Prod Sci 6:219-223. doi:10.1626/pps.6.219

Miyake H, Mitsuya S, Rahman MDS (2006) Ultrastructural effects of salinity stress in higher plants. In: Rai AK, Takabe T (eds) Abiotic stress tolerance in plants. Springer, the Netherlands, pp 215-226

Moberg P, Stahl A, Bhushan S, Wright SJ, Eriksson A, Bruce BD, Glaser E (2003) Characterization of a novel zinc metalloprotease involved in degrading targeting peptides in mitochondria and chloroplasts. Plant J 36:616-628

Molas J (1997) Changes in morphological and anatomical structure of cabbage (Brassica oleracea, L.) outer leaves and in ultrastructure of their chloroplast caused by an in vitro excess of nickel. Photosynthetica 34:513-522. doi:10.1023/A:1006805327340

Molas J (2002) Changes of chloroplast ultrastructure and total chlorophyll concentration in cabbage leaves caused by excess of organic Ni(II) complexes. Environ Exp Bot 47:115-126. doi:10.1016/S0098-8472(01)00116-2

Monteiro MS, Lopes T, Mann RM, Paiva C, Soares AMVM, Santos C (2009) Microsatellite instability in Lactuca sativa chronically exposed to cadmium. Mutat Res 672:90-94. doi:10.1016/j. mrgentox.2008.10.012

Morel M, Crouzet J, Gravot A, Auroy P, Leonhardt N, Vavasseur A, Richaud P (2009) AtHMA3, a P1B-ATPase allowing Cd/Zn/Co/ $\mathrm{Pb}$ vacuolar storage in Arabidopsis. Plant Physiol 149:894-904

Moustakas M, Ouzounidou G, Eleftheriou EP, Lannoye R (1996) Indirect effects of aluminium stress on the function of the photosynthetic apparatus. Plant Physiol Biochem 34:553-560

Moustakas M, Eleftheriou EP, Ouzounidou G (1997) Short-term effects of aluminium at alkaline $\mathrm{pH}$ on the structure and function of the photosynthetic apparatus. Photosynthetica 34:169-177. doi:10.1023/A:1006880205108
Muchuweti M, Birkett JW, Chinyanga E, Zvauya R, Scrimshaw MD, Lester JN (2006) Heavy metal content of vegetables irrigated with mixtures of wastewater and sewage sludge in Zimbabwe: implications for human health. Agric Ecosyst Environ 112:4148. doi:10.1016/j.agee.2005.04.028

Mueller-Roeber B, Arvidsson S (2009) Fertility control: the role of magnesium transporters in pollen development. Cell Res 19:800 801. doi: $10.1038 / \mathrm{cr} .2009 .82$

Myśliwa-Kurdziel B, Strzałka K (2002) Influence of metals on biosynthesis of photosynthetic pigments. In: Prasad MNV, Strzałka K (eds) Physiology and biochemistry of metal toxicity and tolerance in plants. Kluwer, Dordrecht, pp 201-228

Myśliwa-Kurdziel B, Strzałka K (2005) Influence of Cd(II), Cr(VI) and $\mathrm{Fe}(\mathrm{III})$ on early steps of deetiolation process in wheat: fluorescence spectral changes of protochlorophyllide and newly formed chlorophyllide. Agric Ecosyst Environ 106:199-207. doi:10.1016/j.agee.2004.10.008

Myśliwa-Kurdziel B, Prasad MNV, Strzałka K (2002) Impact of heavy metals on photosynthesis. In: Prasad MNV, Strzałka K (eds) Physiology and biochemistry of metal toxicity and tolerance in plants. Kluwer, Dordrecht, pp 229-256

Myśliwa-Kurdziel B, Prasad MNV, Strzałka K (2004) Photosynthesis in heavy metal stressed plants. In: Prasad MNV (ed) Heavy metal stress in plants: from biomolecules to ecosystems. Springer, Berlin, pp 146-181

Nabulo G, Oryem-Origa H, Diamond M (2006) Assessment of lead, cadmium, and zinc contamination of roadside soils, surface films, and vegetables in Kampala City, Uganda. Environ Res 101:4252. doi:10.1016/j.envres.2005.12.016

Nair J, Levitan J, Oyama N (2008) Zinc and copper uptake by silver beet grown in secondary treated effluent. Bioresour Technol 99:2537-2543. doi:10.1016/j.biortech.2007.04.043

Nestel P, Bouis HE, Meenakshi JV, Pfeiffer W (2006) Biofortification of staple food crops. J Nutr 136:1064-1067

Neuhaus HE, Wagner R (2000) Solute pores, ion channels and metabolite transporters in the outer and inner envelope membranes of higher plant plastids. Biochim Biophys Acta 1465:307323. doi:10.1016/S0005-2736(00)00146-2

Nguyen TT, Ngam-Ek A, Jenkins J, Grover SD (1988) Metal ion interactions with phosphoenolpyruvate carboxylase from Crassula argentea and Zea mays. Plant Physiol 86:104-107

Nouairi I, Ben AW, Ben YN, Daoud DBM, Ghorbal MH, Zarrouk M (2006) Comparative study of cadmium effects on membrane lipid composition of Brassica juncea and Brassica napus leaves. Plant Sci 170:511-519. doi:10.1016/j.plantsci.2005.10.003

O'Neal D, Joy KW (1974) Glutamine synthetase of pea leaves. Divalent cation effects, substrate specificity, and other properties. Plant Physiol 54:773-779

Obata H, Umebayashi H (1993) Production of SH compounds in higher plants of different tolerance to Cd. Plant Soil 156:533536. doi:10.1007/BF00025101

Ogundiran MB, Osibanjo O (2008) Heavy metal concentrations in soils and accumulation in plants growing in a deserted slag dumpsite in Nigeria, African. J Biotechnol 7:3053-3060

Ouzounidou G, Moustakas M, Eleftheriou EP (1997) Physiological and ultrastructural effects of cadmium on wheat (Triticum aestivum L.) leaves. Arch Environ Contam Toxicol 32:154-160. doi:10.1007/s002449900168

Ouzounidou G, Moustakas M, Symeonidis L, Karataglis S (2006) Response of wheat seedlings to Ni stress: effects of supplemental calcium. Arch Environ Contam Toxicol 50:346-352. doi:10.1007/s00244-005-5076-3

Oven M, Grill E, Golan-Goldhirsh A, Kutchana TM, Zenk MH (2002) Increase of free cysteine and citric acid in plant cells exposed to cobalt ions. Phytochemistry 60:467-474. doi:10.1016/S00319422(02)00135-8 
Pál M, Horváth E, Janda T, Páldi E, Szalai G (2006) Physiological changes and defense mechanisms induced by cadmium stress in maize. J Plant Nutr Soil Sci 169:1-8. doi:10.1002/ jpln. 200520573

Pál M, Leskó K, Janda T, Páldi E, Szalai G (2007) Cadmiuminduced changes in the membrane lipid composition of maize plants. Cereal Res Commun 35:1631-1642. doi:10.1556/ CRC.35.2007.4.10

Palmgren MG, Harper JF (1999) Pumping with plant P-type ATPases. J Exp Bot 50:883-893. doi:10.1093/jxb/50

Palmgren MG, Clemens S, Williams LE, Krämer U, Borg S, Schjørring JK, Sanders D (2008) Zinc biofortification of cereals: problems and solutions. Trends Plant Sci 13:464-473. doi:10.1016/j.tplants.2008.06.005

Panda SK (2007) Chromium-mediated oxidative stress and ultrastructural changes in root cells of developing rice seedlings. J Plant Physiol 164:1419-1428. doi:10.1016/j.jplph.2007.01.012

Panda SK, Chaudhury I, Khan MH (2003) Heavy metals induce lipid peroxidation and affect antioxidants in wheat leaves. Biol Plant 46:289-294. doi:10.1023/A:1022871131698

Pandey J, Pandey U (2009) Accumulation of heavy metals in dietary vegetables and cultivated soil horizon in organic farming system in relation to atmospheric deposition in a seasonally dry tropical region of India. Environ Monit Assess 148:61-74. doi:10.1007/ s10661-007-0139-8

Pandey N, Sharma CP (2002) Effect of heavy metals $\mathrm{Co}^{2+}, \mathrm{Ni}^{2+}$ and $\mathrm{Cd}^{2+}$ on growth and metabolism of cabbage. Plant Sci 163:753758. doi:10.1016/S0168-9452(02)00210-8

Panou-Filotheou H, Bosabalidis AM, Karataglis S (2001) Effects of copper toxicity on leaves of oregano (Origanum vulgare subsp. hirtum). Ann Bot 88:207-214. doi:10.1006/anbo.2001.1441

Papadakis IE, Giannakoula A, Therios IN, Bosabalidis AM, Moustakas M, Nastou A (2007) Mn-induced changes in leaf structure and chloroplast ultrastructure of Citrus volkameriana (L.) plants. J Plant Physiol 164:100-103. doi:10.1016/j.jplph.2006.04.011

Peris M, Micó C, Recatalá L, Sánchez R, Sánchez J (2007) Heavy metal contents in horticultural crops of a representative area of the European Mediterranean region. Sci Total Environ 378:42 48. doi:10.1016/j.scitotenv.2007.01.030

Picault N, Cazalé AC, Beyly A, Cuiné S, Carrier P, Luu DT, Forestier C, Peltier G (2006) Chloroplast targeting of phytochelatin synthase in Arabidopsis: effects on heavy metal tolerance and accumulation. Biochimie 88:1743-1750. doi:10.1016/j.biochi. 2006.04.016

Pilon M, Cohu CM, Ravet K, Abdel-Ghany SE, Gaymard F (2009) Essential transition metal homeostasis in plants. Curr Opin Plant Biol 12:347-357. doi:10.1016/j.pbi.2009.04.011

Pinto AP, Mota AM, de Varennes A, Pinto FC (2004) Influence of organic matter on the uptake of cadmium, zinc, copper and iron by sorghum plants. Sci Total Environ 326:239-247. doi:10.1016/ j.scitotenv.2004.01.004

Platt-Aloia KA, Thomson WW, Terry N (1983) Changes in plastid ultrastructure during iron nutrition-mediated chloroplast development. Protoplasma 114:85-92. doi:10.1007/BF01279871

Podar D, Ramsey MH, Hutchings MJ (2004) Effect of cadmium, zinc and substrate heterogeneity on yield, shoot metal concentration and metal uptake by Brassica juncea: implication for human health risk assessment and phytoremediation. New Phytol 163:313-324. doi:10.1111/j.1469-8137.2004.01122.x

Poirier I, Jean N, Bertrand M (2008) Plastids and metals. In: Schoefs B (ed) Plant cell organelles - selected topics. Research Sign Post, Trivandrum, Kerala, pp 285-307

Poschenrieder C, Vázquez MD, Bonet A, Barceló J (1991) Chromium-III-iron interaction in iron sufficient and iron deficient bean plants. 2. Ultrastructural aspects. J Plant Nutr 14:415428. doi:10.1080/01904169109364212
Poschenrieder C, Gunsé B, Corrales I, Barceló J (2008) A glance into aluminum toxicity and resistance in plants. Sci Total Environ 400:356-368. doi:10.1016/j.scitotenv.2008.06.003

Possingham JV, Vesk M, Mercer FV (1964) The fine structure of leaf cells of manganese-deficient spinach. J Ultrastruct Res 11:68-83. doi:10.1016/S0022-5320(64)80093-9

Prasad MNV (2004) Heavy metal stress in plants: from biomolecules to ecosystems. Springer, Berlin

Puig S, Penarrubia L (2009) Placing metal micronutrients in context: transport and distribution in plants. Curr Opin Plant Biol 12:299 306. doi:10.1016/j.pbi.2009.04.008

Puig S, Andres-Colas N, García-Molina A, Penarrubia L (2007a) Copper and iron homeostasis in Arabidopsis: responses to metal deficiencies, interactions and biotechnological applications. Plant Cell Environ 30:271-290. doi:10.1111/j.1365-3040.2007.01642.x

Puig S, Mira H, Dorcey E, Sancenón V, Andrés-Colás N, GarciaMolina A, Burkhead JL, Gogolin KA, Abdel-Ghany SE, Thiele DJ, Ecker JR, Pilon M, Penarrubia L (2007b) Higher plants possess two different types of ATX1-like copper chaperones. Biochem Biophys Res Commun 354:385-390. doi:10.1016/j. bbrc.2006.12.215

Quartacci MF, Pinzino C, Sgherri CLM, Dalla VF, Navari-Izzo F (2000) Growth in excess copper induces changes in the lipid composition and fluidity of PSII-enriched membranes in wheat. Physiol Plant 108:87-93. doi:10.1034/j.1399-3054.2000.108001087.x

Radmer R, Kok B (1974) Kinetic observation of the system II electron acceptor pool isolated by mercury ion. Biochim Biophys Acta 337:177-180

Rahman MS, Matsumuro T, Miyake H, Takeoka Y (2000) Salinityinduced ultrastructural alterations in leaf cells of rice (Oryza sativa L.). Plant Prod Sci 3:422-429

Ramos I, Esteban E, Lucena JJ, Gárate A (2002) Cadmium uptake and subcellular distribution in plants of Lactuca sp. Cd-Mn interaction. Plant Sci 162:761-767. doi:10.1016/S0168-9452(02)00017-1

Ranathunge K, Steudle E, Lafitte R (2005) A new precipitation technique provides evidence for the permeability of Casparian bands to ions in young roots of corn (Zea mays L.) and rice (Oryza sativa L.). Plant Cell Environ 28:1450-1462. doi:10.1111/j.1365-3040.2005.01391.x

Randall PJ, Bouma D (1973) Zinc deficiency, carbonic anhydrase, and photosynthesis in leaves of spinach. Plant Physiol 52:229-232

Rattan RK, Datta SP, Chhonkar PK, Suribabu K, Singh AK (2005) Long-term impact of irrigation with sewage effluents on heavy metal content in soils, crops and groundwater-a case study. Agric Ecosyst Environ 109:310-322. doi:10.1016/ j.agee.2005.02.025

Raven JA, Evans MCW, Korb RE (1999) The role of trace metals in photosynthetic electron transport in $\mathrm{O}_{2}$-evolving organisms. Photosynth Res 60:111-150. doi:10.1023/A:1006282714942

Ravet K, Touraine B, Kim SA, Cellier F, Thomine S, Guerinot ML, Briat JF, Gaymard F (2009) Post-translational regulation of AtFER2 ferritin in response to intracellular iron trafficking during fruit development in Arabidopsis. Mol Plant 2:10951106. doi: $10.1093 / \mathrm{mp} / \mathrm{ssp} 041$

Rengel Z (1997) Root exudation and microflora populations in rhizosphere of crop genotypes differing in tolerance to micronutrient deficiency. Plant Soil 196:255-260

Rodríguez-Serrano M, Romero-Puertas MC, Pazmino DM, Testillano PS, Risueno MC, del Río LA, Sandalio LM (2009) Cellular response of pea plants to cadmium toxicity: cross talk between reactive oxygen species, nitric oxide, and calcium. Plant Physiol 150:229-243

Romanowska E (2002) Gas exchange functions in metal stressed plants. In: Prasad MNV, Strzałka K (eds) Physiology and biochemistry of metal toxicity and tolerance in plants. Kluwer, Dordrecht, pp 257-285 
Sabnis DD, Gordon M, Galsto AW (1969) A site with an affinity for heavy metals on the thylakoid membranes of chloroplasts. Plant Physiol 44:1355-1363

Sagardoy R, Morales F, Lopez-Millan AF, Abadia A, Abadia J (2009) Effects of zinc toxicity on sugar beet (Beta vulgaris L.) plants grown in hydroponics. Plant Biol 11:339-350. doi:10.1111/ j.1438-8677.2008.00153.x

Sahn RK, Katiyar S, Tiwari J, Kisku GC (2007) Assessment of drain water receiving effluent from tanneries and its impact on soil and plants with particular emphasis on bioaccumulation of heavy metals. J Environ Biol 28:685-690

Salama S, Trivedi S, Busheva M, Arafa AA, Garab G, Erdei L (1994) Effects of $\mathrm{NaCl}$ salinity on growth, cation accumulation, chloroplast structure and function in wheat cultivars differing in salt tolerance. J Plant Physiol 144:241-247

Sam O, Ramirez C, Coronado MJ, Testillano PS, Risueno MC (2003) Changes in tomato leaves induced by $\mathrm{NaCl}$ stress: leaf organization and cell ultrastructure. Biol Plant 47:361-366. doi:10.1023/B:BIOP.0000023878.58899.88

Sancenon V, Puig S, Mira H, Thiele DJ, Penarrubia L (2003) Identification of a copper transporter family in Arabidopsis thaliana. Plant Mol Biol 51:577-587. doi:10.1023/ A:1022345507112

Sandalio LM, Dalurzo HC, Gómez M, Romero-Puertas MC, del Rio LA (2001) Cadmium-induced changes in the growth and oxidative metabolism of pea plants. J Exp Bot 52:2115-2126. doi:10.1093/jexbot/52.364.2115

Sárvári É (2005) Effects of heavy metals on chlorophyll-protein complexes in higher plants: causes and consequences. In: Pessarakli M (ed) Handbook of photosynthesis. CRC, Boca Raton, pp 865-888

Sasaki Y, Nagano Y, Morioka S, Ishikawa H, Matsuno R (1989) A chloroplast gene encoding a protein with one zinc finger. Nucleic Acids Res 17:6217-6227. doi:10.1093/nar/17.15.6217

Schmidt W (2003) Iron solutions: acquisition strategies and signaling pathway in plants. Trends Plant Sci 8:188-193. doi:10.1016/ S1360-1385(03)00048-7

Schoefs B (2005) Protochlorophyllide reduction - what is new in 2005? Photosynthetica 43:329-343

Seddas P, Gianinazzi-Pearson V, Schoefs B, Küster H, Wipf D (2009) Communication and signaling in the plant-fungus symbiosis: the mycorrhiza. In: Beluska F (ed) Plant-environment interactions. Signaling and communication in plants. Springer, Berlin, pp 45-71

Seigneurin-Berny D (2000) Recherche de nouveaux systèmes de transport à travers l'enveloppe du chloroplaste. Characterisation de nouvelles protéines hydrophobes. PhD thesis, Université Joseph Fourier-Grenoble I, France (in French)

Seigneurin-Berny D, Gravot A, Auroy P, Mazard C, Kraut A, Finazzi G, Grunwald D, Rappaport F, Vavasseur A, Joyard J, Richaud P, Rolland N (2006) HMA1, a new Cu-ATPase of the chloroplast envelope, is essential for growth under adverse light conditions. J Biol Chem 281:2882-2892. doi:10.1074/jbc.M508333200

Shalygo NV, Kolesnikova NV, Voronetskaya VV, Averina NG (1999) Effects of $\mathrm{Mn}^{2+}, \mathrm{Fe}^{2+}, \mathrm{Co}^{2+}$ and $\mathrm{Ni}^{2+}$ on chlorophyll accumulation and early stages of chlorophyll formation in greening barley seedlings. Russian J Plant Physiol 46:496-501

Sharma SS, Dietz K-J (2009) The relationship between metal toxicity and cellular redox imbalance. Trends Plant Sci 14:43-50. doi:10.1016/j.tplants.2008.10.007

Sharma RK, Agrawal M, Marshall FM (2008a) Atmospheric deposition of heavy metals $(\mathrm{Cu}, \mathrm{Zn}, \mathrm{Cd}$ and $\mathrm{Pb})$. Environ Monit Assess 142:269-278. doi:10.1007/s10661-007-9924-7

Sharma RK, Agrawal M, Marshall FM (2008b) Heavy metal (Cu, Zn, $\mathrm{Cd}$ and $\mathrm{Pb}$ ) contamination of vegetables in urban India: a case study in Varanasi. Environ Pollut 154:254-263. doi:10.1016/j. envpol.2007.10.010
Shaul O (2002) Magnesium transport and function in plants: the tip of the iceberg. Biometals 15:309-323. doi:10.1023/A: 1016091118585

Shikanai T, Müller-Moulé P, Munekage Y, Niyogi KK, Pilon M (2003) PAA1, a P-type ATPase of Arabidopsis, functions in copper transport in chloroplasts. Plant Cell 15:1333-1346

Siedlecka A, Krupa Z (1996) Interaction between cadmium and iron and its effects on photosynthetic capacity of primary leaves of Phaseolus vulgaris. Plant Physiol Biochem 34:833-841

Siedlecka A, Krupa Z (1999) $\mathrm{Cd} / \mathrm{Fe}$ interaction in higher plants - its consequences for the photosynthetic apparatus. Photosynthetica 36:321-331

Singh RP, Agrawal M (2007) Effects of sewage sludge amendment on heavy metal accumulation and consequent responses of Beta vulgaris plants. Chemosphere 67:2229-2240. doi:10.1016/j. chemosphere.2006.12.019

Singh S, Sinha S (2005) Accumulation of metals and its effect in Brassica juncea (L.) Czern. (cv. Rohini) grown on various amendments of tannery waste. Ecotox Environ Saf 62:118-127. doi:10.1016/j.ecoenv.2004.12.026

Sinha P, Dube BK, Srivastava P, Chatterjee C (2006) Alteration in uptake and translocation of essential nutrients in cabbage by excess lead. Chemosphere 65:651-656. doi:10.1016/j.chemo sphere.2006.01.068

Skórzyńska E, Baszyński T (1993) The changes in PS II complex peptides under cadmium treatment are they of direct or indirect nature? Acta Physiol Plant 15:263-269

Skórzyńska E, Urbanik-Sypiewska T, Russa R, Baszyński T (1991) Galactolipase activity in Cd-treated runner bean plants. J Plant Physiol 138:454-459

Skórzyńska-Polit E, Baszyński T (1997) Differences in sensitivity of the photosynthetic apparatus in Cd-stressed runner bean plants in relation to their age. Plant Sci 128:11-21. doi:10.1016/S01689452(97)00126-X

Skórzyńska-Polit E, Krupa Z (2006) Lipid peroxidation in cadmiumtreated Phaseolus coccineus plants. Arch Environ Contam Toxicol 50:482-487. doi:10.1007/s00244-005-0125-5

Skórzyńska-Polit E, Tukendorf A, Selstam E, Baszyński T (1998) Calcium modifies Cd effect on runner bean plants. Environ Exp Bot 40:275-286. doi:10.1016/S0098-8472(98)00045-8

Solti Á, Gáspár L, Mészáros I, Szigeti Z, Lévai L, Sárvári É (2008) Impact of iron supply on the kinetics of recovery of photosynthesis in Cd-stressed poplar (Populus glauca). Ann Bot 102:771782. doi:10.1093/aob/men160

Solymosi K, Lenti K, Myśliwa-Kurdziel B, Fidy J, Strzałka K, Böddi $\mathrm{B}(2004) \mathrm{Hg}^{2+}$ reacts with different components of the NADPH: protochlorophyllide oxidoreductase macrodomains. Plant Biol 6:358-368. doi:10.1055/s-2004-817893

Solymosi K, Myśliwa-Kurdziel B, Bóka K, Strzałka K, Böddi B (2006) Disintegration of the prolamellar body structure at high concentrations of $\mathrm{Hg}^{2+}$. Plant Biol 8:627-635. doi:10.1055/s-2006924110

Song C-P, Gui Y, Qui Q, Lambert G, Galbraith DW, Jagendorf A (2004a) A probable $\mathrm{Na}^{+}\left(\mathrm{K}^{+}\right) / \mathrm{H}^{+}$exchanger on the chloroplast envelope functions in $\mathrm{pH}$ homeostasis and chloroplast development in Arabidopsis thaliana. Proc Natl Acad Sci USA 101:10211-10216. doi:10.1073/pnas.0403709101

Song W-Y, Martinoia E, Lee J, Kim D, Kim D-Y, Vogt E, Shim D, Choi KS, Hwang I, Lee Y (2004b) A novel family of cys-rich membrane proteins mediates cadmium resistance in Arabidopsis. Plant Physiol 135:1027-1039. doi:10.1104/pp.103.037739

Sors TG, Ellis DR, Salt DE (2005) Selenium uptake, translocation, assimilation and metabolic fate in plants. Photosynth Res 86:373-389. doi:10.1007/s11120-005-5222-9

Spetea C, Schoefs B (2011) Photosynthesis and light stress in a model plant-role of chloroplast transporters. In: Pessarakli M (ed) 
Handbook of plant and crop stress, 3rd edn. Taylor \& Francis, Boca Raton, pp. 361-389

Srivastava NK, Misra A, Sharma S (1997) Effect of Zn deficiency on net photosynthetic rate, ${ }^{14} \mathrm{C}$ partitioning, and oil accumulation in leaves of peppermint. Photosynthetica 33:71-79. doi:10.1023/ A: 1022127305883

Stefanov S, Pandev SD, Seizova K, Tyankova LA, Popov S (1995) Effect of lead on the lipid metabolism in spinach leaves and thylakoid membranes. Biol Plant 37:251-256. doi:10.1007/ BF02913222

Stobart AK, Griffiths WT, Ameen-Bukhari I, Sherwood RP (1985) The effect of $\mathrm{Cd}^{2+}$ on the biosynthesis of chlorophyll in leaves of barley. Physiol Plant 63:293-298. doi:10.1111/j.1399-3054.1985. tb04268.x

Subbarao GV, Stutte GW, Wheeler RM, Berry WL (2001) Sodium: a functional nutrient in plants. In: Pessarakli M (ed) Handbook of plant and crop physiology. Marcel Dekker, New York, pp 363-384

Takeuchi Y, Akagi H, Kamasawa N, Osumi M, Honda H (2000) Aberrant chloroplasts in transgenic rice plants expressing a high level of maize NADP-dependent malic enzyme. Planta 211:265274. doi: $10.1007 / \mathrm{s} 004250000282$

Thoiron S, Pascal N, Briat J-F (1997) Impact of iron deficiency and iron re-supply during the early stages of vegetative development in maize (Zea mays L). Plant Cell Environ 20:1051-1060. doi:10.1111/j.1365-3040.1997.tb00681.x

Thomine S, Wang R, Ward JM, Crawford NM, Schroeder JI (2000) Cadmium and iron transport by members of a plant metal transporter family in Arabidopsis with homology to Nramp genes. Proc Natl Acad Sci USA 97:4991-4996

Thomson WW, Weier E (1962) The fine structure of chloroplasts from mineral deficient leaves of Phaseolus vulgaris. Am J Bot 49:1047-1055

Timperio AM, D'Amici GM, Barta C, Loreto F, Zolla L (2007) Proteomics, pigment composition, and organization of thylakoid membranes in iron-deficient spinach leaves. J Exp Bot 58:36953710. doi:10.1093/jxb/erm219

Tognetti VB, Zurbriggen MD, Morandi EN, Fillat MF, Valle EM, Hajirezaei M-R, Carrill N (2007) Enhanced plant tolerance to iron starvation by functional substitution of chloroplast ferredoxin with a bacterial flavodoxin. Proc Natl Acad Sci USA 104:11495-11500. doi:10.1073/pnas.0704553104

Vallee BL, Ulmer DD (1972) Biochemical effects of mercury, cadmium and lead. Annu Rev Biochem 41:91-128

Van der Vere PS, Bennett TM, Oblong JE, Lamppa GK (1995) A chloroplast processing enzyme involved in precursor maturation shares a zinc-binding motif with a recently recognized family of metalloendopeptidases. Proc Natl Acad Sci USA 92:7177-7181

Varga A, Martinez RMG, Záray G, Fodor F (1999) Investigation of effects of cadmium, lead, nickel and vanadium contamination on the uptake and transport processes in cucumber plants by TXRF spectrometry. Spectrochim Acta B 54:1455-1462. doi:10.1016/ S0584-8547(99)00105-6

Vázquez MD, Poschenrieder C, Barceló J (1987) Chromium VI induced structural and ultrastructural changes in bush bean plants (Phaseolus vulgaris L.). Ann Bot 59:427-428

Vázquez MD, Bennassar $\mathrm{A}$, Cabot $\mathrm{C}$, Poschenrieder $\mathrm{C}$, Barceló $\mathrm{J}$ (1990) Phytotoxic effects of technetium-99 in beans: influence of cotyledon excision. Environ Exp Bot 30:271-281. doi:10.1016/ 0098-8472(90)90039-7

Verret F, Gravot A, Auroy P, Leonhardt N, David P, Nussaume L, Vavasseur A, Richaud P (2004) Overexpression of AtHMA4 enhances root-to-shoot translocation of zinc and cadmium and plant metal tolerance. FEBS Lett 576:306-312

Walker EL, Connolly EL (2008) Time to pump iron: iron-deficiencysignaling mechanisms of higher plants. Curr Opin Plant Biol 11:530-535. doi:10.1016/j.pbi.2008.06.013
Wang CQ, Song H (2009) Calcium protects Trifolium repens L. seedlings against cadmium stress. Plant Cell Rep 28:1341-1349. doi:10.1007/s00299-009-0734-y

Wang W, Vinocur B, Altman A (2003) Plant responses to drought, salinity and extreme temperatures: towards genetic engineering for stress tolerance. Planta 218:1-14. doi:10.1007/s00425-003$1105-5$

Wang C, Zhang SH, Wang PF, Hou J, Zhang WJ, Li W, Lin ZP (2009) The effect of excess $\mathrm{Zn}$ on mineral nutrition and antioxidative response in rapeseed seedlings. Chemosphere 75:1468-1476. doi:10.1016/j.chemosphere.2009.02.033

Weber APM, Schwacke R, Flügge U-I (2005) Solute transporters of the plastid envelope membrane. Annu Rev Plant Biol 56:133164. doi:10.1146/annurev.arplant.56.032604.144228

Wei B, Yang L (2010) A review of heavy metal contaminations in urban soils, urban road dusts and agricultural soils from China. Microchem J 94:99-107

Wei S, Zhou Q (2008) Trace elements in agro-ecosystems. In: Prasad MNV (ed) Trace elements as contaminants and nutrients consequences in ecosystems and human health. Wiley, New Jersey, pp 55-80

Weiland RT, Noble RD, Crang RE (1975) Photosynthetic and chloroplast ultrastructural consequences of manganese deficiency in soybean. Am J Bot 62:501-508

Wenzel WW (2009) Rhizosphere processes and management in plantassisted bioremediation (phytoremediation) of soils. Plant Soil 321:385-408. doi:10.1007/s11104-008-9686-1

Weryszko-Chmielewska E, Chwil M (2005) Lead-induced histological and ultrastructural changes in the leaves of soybean (Glycine max (L.) Merr.). Soil Sci Plant Nutr 51:203-212. doi:10.1111/j.17470765.2005.tb00024.x

White PJ, Broadley MR (2003) Calcium in plants. Ann Bot 92:487511. doi:10.1093/aob/mcg164

White PJ, Broadley MR (2009) Biofortification of crops with seven mineral elements often lacking in human diets-iron, zinc, copper, calcium, magnesium, selenium and iodine. New Phytol 182:49-84. doi:10.1111/j.1469-8137.2008.02738.x

Whiting SN, Broadley MR, White PJ (2003) Applying a solute transfer model to phytoextraction: zinc acquisition by Thlaspi caerulescens. Plant Soil 249:45-56. doi:10.1023/A:1022542725880

Williams LE, Mills RF (2005) P(1B)-ATPases: an ancient family of transition metal pumps with diverse functions in plants. Trends Plant Sci 10:491-502. doi:10.1016/j.tplants.2005.08.008

Wilson B, Pyatt FB (2007) Heavy metal bioaccumulation by the important food plant, Olea europaea L., in an ancient metalliferous polluted area of Cyprus. Bull Environ Contam Toxicol 78:390-394. doi:10.1007/s00128-007-9162-2

Wintz H, Vulpe C (2002) Intracellular trafficking. Plant copper chaperones. Biochem Soc Trans 30:732-735

Wintz H, Fox T, Vulpe C (2002) Functional genomics and gene regulation in biometals research. Responses of plants to iron, zinc and copper deficiencies. Biochem Soc Trans 30:766768

Witter E (1996) Towards zero accumulation of heavy metals in soils. An imperative or a fad? Fertil Res 43:225-233. doi:10.1007/ BF00747706

Woźny A, Schneider J, Gwozdz EA (1995) The effects of lead and kinetin on greening barley leaves. Biol Plant 37:541-552. doi:10.1007/BF02908836

Wu S, Zhou S, Li X, Zhang H, Ren K, Zhao Q (2009) Estimating the anthropogenic fluxes of heavy metal accumulations in roadside agricultural soils. Fresenius Environ Bull 18:1336-1340

Yamane K, Kawasaki M, Taniguchi M, Miyake H (2003) Differential effect of $\mathrm{NaCl}$ and polyethylene glycol on the ultrastructure of chloroplasts in rice seedlings. J Plant Physiol 160:573-575. doi:10.1078/0176-1617-00948 
Yamane K, Rahman MDS, Kawasaki M, Taiguchi M, Miyake H (2004) Pretreatment with antioxidants decreases the effects of salt stress on chloroplast ultrastructure in rice leaf segments (Oryza sativa L.). Plant Prod Sci 7:292-300. doi:10.1626/ pps.7.292

Yamane K, Kawasaki M, Taniguchi M, Miyake H (2008) Correlation between chloroplast ultrastructure and chlorophyll fluorescence characteristics in the leaves of rice (Oryza sativa L.) grown under salinity. Plant Prod Sci 11:139-145. doi:10.1626/pps.11.139

Yamane K, Mitsuya S, Kawasaki M, Taniguchi M, Miyake H (2009) Antioxidant capacity and damages caused by salinity stress in apical and basal regions of rice leaf. Plant Prod Sci 12:319-326. doi:10.1626/pps.12.319

Yang XE, Chen WR, Feng Y (2007) Improving human micronutrient nutrition through biofortification in the soil-plant system: China as a case study. Environ Geochem Health 29:413-428. doi:10.1007/s10653-007-9086-0
Yruela I (2009) Copper in plants: acquisition, transport and interactions. Funct Plant Biol 36:409-430. doi:10.1071/FP08288

Yu Q, Osborne LD, Rengel Z (1999) Increased tolerance to Mn deficiency in transgenic tobacco overproducing superoxide dismutase. Ann Bot 84:543-547. doi:10.1006/anbo.1999.0951

Zhang H, Jiang Y, He Z, Ma M (2005) Cadmium accumulation and oxidative burst in garlic (Allium sativum). J Plant Physiol 162:977-984. doi:10.1016/j.jplph.2004.10.001

Zhang L, Zhang L, Song F (2008) Cadmium uptake and distribution by different maize genotypes in maturing stage. Commun Soil Sci Plant Anal 39:1517-1531. doi:10.1080/00103620802006651

Zhang J, Sun W, Li Z, Liang Y, Song A (2009) Cadmium fate and tolerance in rice cultivars. Agron Sustain Dev 29:483-490. doi:10.1051/agro/2009008

Zhao ZQ, Zhu YG, Kneer R, Smith RE (2005) Effect of zinc on cadmium toxicity-induced oxidative stress in winter wheat seedlings. J Plant Nutr 28:1947-1959. doi:10.1080/01904160500310955 